\title{
Stratigraphic correlations between the Brabant Massif and the Stavelot, Rocroi and Givonne inliers (Belgium) and geological implications
}

\author{
To Michel Vanguestaine, with my respect for his outstanding pioneering work
}

\section{ALAIN HERBOSCH}

Université Libre de Bruxelles, Département Géosciences, Environnement et Société, Avenue F.D. Roosevelt, 50, 1050 Brussels, Belgium; Alain.Herbosch@ulb.ac.be.

\begin{abstract}
The Caledonian basement crops out in the middle and southern part of Belgium in two major tectonic units: the Brabant Massif in the Brabant Parautochthon and the Stavelot-Venn, Rocroi, Givonne and Serpont inliers in the Ardenne Allochthon. The main aim of this work is to achieve a chronostratigraphic correlation between the Brabant Massif and the Ardenne inliers, from the lower Cambrian to the Middle Ordovician. Throughout his career, Michel Vanguestaine established an informal acritarch biozonation for this basement, which is only linked to the international stratigraphic scale in vigour at that time. Our first step was to correlate these informal biozones with the trilobite (Cambrian) and graptolite (Ordovician) biozonations which are currently well correlated with the chronostratigraphy. Then, compilation of the literature concerning each of these sedimentary units makes it possible to assign a chronostratigraphic position to their constituent formations. This work has permitted the establishment of a complete chart of the stratigraphic correlations between the Brabant Massif and the three main Ardenne inliers (Stavelot-Venn, Rocroi and Givonne). Geological implications are discussed: the Brabant Massif and the Ardenne inliers formed a single sedimentation basin with different and rheologically contrasting basements (rift and shoulder). New arguments confirm the presence of a Caledonian orogeny in the Ardenne.
\end{abstract}

KEYWORDS: Belgian Caledonian basement, E Avalonia, Ardenne inliers, acritarch biozonation, biostratigraphy.

\section{Introduction}

The last complete accounts of the comparative stratigraphy of the Belgian Caledonian basement, namely the Brabant Massif and the Ardenne inliers (Vanguestaine, 1992; Verniers et al., 2001, 2002) are becoming dated. Indeed, in the last 20 years, progress in the study of the Belgian Lower Palaeozoic stratigraphy, but also of the global stratigraphy (Ogg et al., 2008; Gradstein et al., 2012, 2020) has greatly increased, which justifies the present work.

The Caledonian basement crops out in the southern half of Belgium and neighbouring countries, where it is observed in two major tectonic units: the Brabant Parautochthon to the $\mathrm{N}$ and the Ardenne Allochthon to the S (Fig. 1). The latter belongs to the westernmost part of the Rheno-Hercynian domain and is close to the Variscan front. The Midi-Eifel-Aachen Thrust Fault displaced the Ardenne Allochthon several tens of $\mathrm{km}$ to the $\mathrm{N}$, as shown by deep seismic investigations (see recent overview in Mancy \& Lacquement, 2006; Meilliez \& Lacquement, 2020). This northern shift is responsible for the formation of frequently overturned thrusts sheets which also incorporated Lower Palaeozoic units as for example in the Condroz Inlier (e.g. Bélanger et al., 2012). The Brabant Massif can be observed in the valleys that incise its southern rim but it is also present to the $\mathrm{N}$ under the Mesozoic and Cenozoic cover. In the Ardenne Allochthon the Caledonian basement is exposed in four inliers: Stavelot-Venn Inlier (SVI), Rocroi Inlier, Givonne Inlier and Serpont Inlier in descending order of area. These are disconnected from the underlying parts of the Caledonian basement by the Variscan thrusting. The Caledonian basement of Belgium and neighbouring countries belongs to the Avalonia microcontinent (e.g. Verniers et al., 2002; Winchester et al., 2002; Cocks \& Torsvik, 2005; 2021). Palaeogeographic models for the Early Palaeozoic reveal notable differences between different authors; the reader is referred to the recent models of Domeier (2016) and Cocks \& Torsvik (2021) in which the PeriGondwanian terranes such as Avalonia E and W, Ganderia and Carolinia are shown to have rifted and drifted on a single plate until just prior to their accretion with Baltica and Laurentia.

\section{Informal acritarch biozones of Vanguestaine and methodology used in the work}

\subsection{The informal acritarch biozones established by Vanguestaine and co-workers}

Since his $\mathrm{PhD}$ thesis in 1973, Michel Vanguestaine did not cease to ameliorate, change and extend his informal biostratigraphic scale based on acritarch associations by applying it in areas of the Cambrian and Ordovician inliers of Stavelot-Venn Inlier, Rocroi Inlier and Givonne Inlier as well as to the Brabant Massif. This pioneering work, carried out in part with his students and colleagues, spanned more than 40 years and was interrupted by his early death. His scale (Vanguestaine, 1986; 1992) comprised 13 informal zones ranging from Zone 0 to Zone 9, including zones $4 \mathrm{a}, 4 \mathrm{~b}$, cf 5 and $\mathrm{cf} 6$. This scale is currently only partially and imperfectly correlated with the international stratigraphic scale except for the Brabant Massif (Linnemann et al., 2012; Herbosch \& Verniers, 2013, 2014) and the Stavelot-Venn Inlier (Herbosch et al., 2020).

\subsection{Methodology adopted in this work}

Given the scarcity of other fossils than acritarchs in the sedimentary strata of the Belgian Caledonian basement, the chronostratigraphical dating of the Cambro-Ordovician acritarch biozones in Belgium always was established indirectly, through intermediate steps as correlations from biozonations made with other fossil groups established abroad. I therefore started by listing the most recent published biozonations for Cambrian trilobites and Ordovician graptolites (Peng et al., 2020; Goldman et al., 2020). Then, all publications of Vanguestaine and co-authors were analysed in an attempt to link the different informal acritarch zones they published to the internationally established trilobite and graptolite biozonations. This should allow attributing these informal zones with the most recently established international chronostratigraphy (Gradstein et al., 2020). The comparison is restricted to the time interval from the upper part of Cambrian Stage 2 (Terreneuvian Series) to the lower part of the Darriwilian (Middle Ordovician), interval 


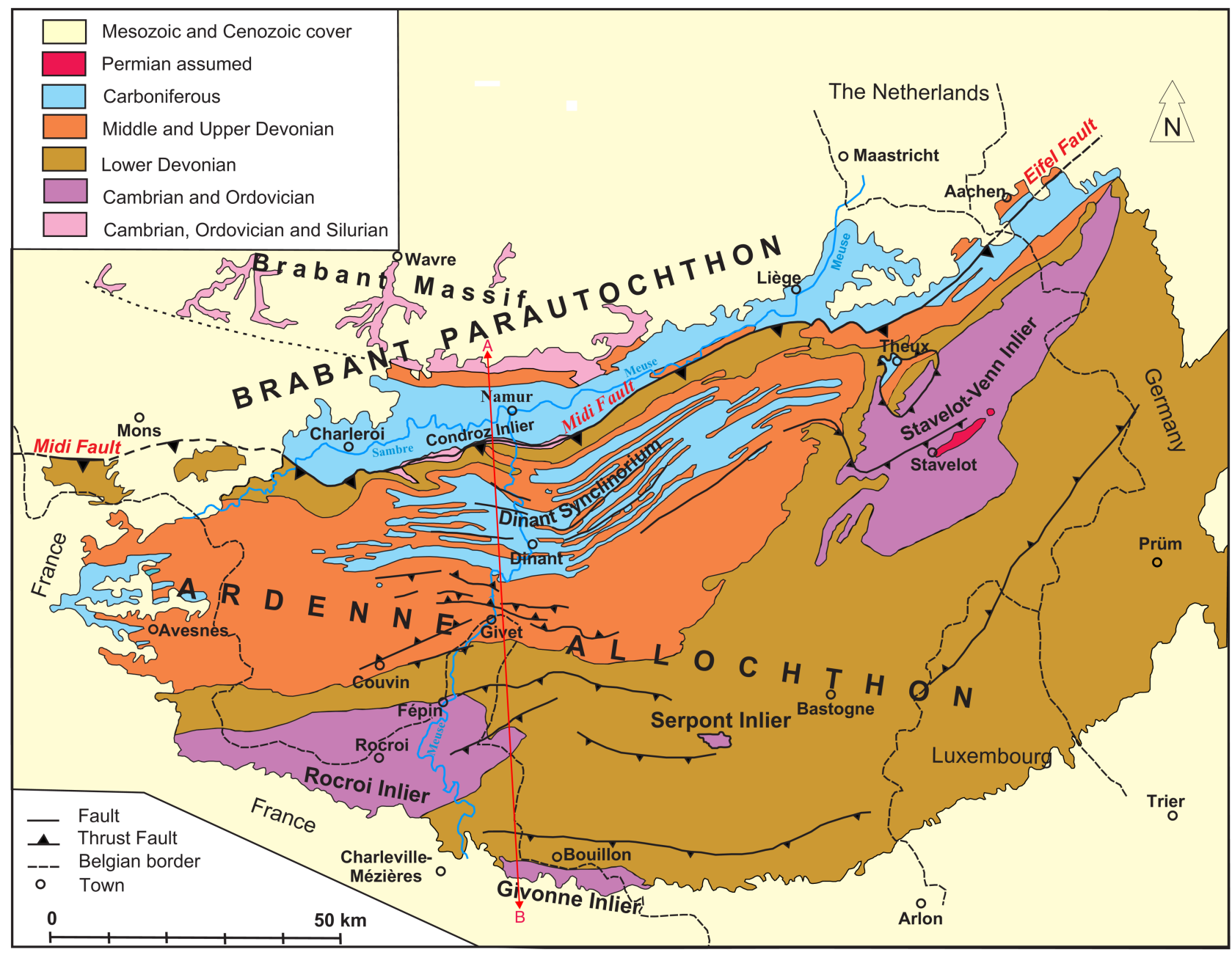

Figure 1. Simplified geological map of the southern part of Belgium and neighbouring countries showing the main tectonostratigraphic units of the Palaeozoic. To the N the Brabant Parautochthon is separated from the Ardenne Allochthon by the Midi-Aachen Thrust Fault. The four Ardenne inliers, Stavelot-Venn, Rocroi, Givonne and Serpont, are represented in purple. The N-S red line is the trace of the section of the Fig. 6. Modified from Herbosch et al. (2020).

which corresponds to the sedimentary record of the Ardenne inliers (Verniers et al., 2001; 2002).

\section{The trilobite biozonation for the Cambrian}

Peng et al. (2020, fig. 19.2) list the most recent trilobite biozonation data for Baltica (no data for Gondwana) from the middle Wuliuan to the top of the Cambrian. For Stages 2 to 4 , an interval where formally no trilobite biozonation has yet been established, the "Correlation chart for major Cambrian areas" in the E Avalonia region (Geyer et al., in Geyer \& Shergold, 2000) is used.

\section{The graptolite biozonation for the Ordovician}

Goldman et al. (2020, figs 20.3 and 20.4) provide the most recent data on the graptolites biozonation from Britain. For the Tremadocian, the biozonation of Goldman et al. (2020, fig. 20.4, Baltica column) is used as is more adapted to the Belgian biozonation used by Wang \& Servais (2015).

\section{Correlation of the Vanguestaine informal acritarch biozones with the recent global chronostratigraphy}

\subsection{Zone 0}

The taxa in Zone 0 are present in the interval that includes the undifferentiated Olenellid and the Protolenid-Strenuellid trilobite biozones of E Avalonia (sensu Geyer \& Shergold, 2000). Indeed, Vanguestaine (1991, p. 223) attributed the association found in the Oisquercq Formation (Fm) of the Lessines borehole to the lower Cambrian. This conclusion was confirmed by Vanguestaine et al. (2001, p. 68) who showed that this same association was restricted to the lower Cambrian in the higher parts of the Bray Group (Ireland) where in the vicinity of the sampling Oldhamia was found. The stratigraphy of the "lower Cambrian" has been refined in recent years and the Bray Group is attributed now to global stages 3 and 4 . However, in those two stages, no formal trilobite biozones have been established yet particularly not in Avalonia, a microcontinent not included in the Cambrian overview tables of Gradstein et al. (2012, 2020). But when Peng et al. (2020, p. 575) wrote: "Stage 4 spans almost the entire range of Olenellus (s.1.) and Redlichia (s.1.), the representative forms of the "olenellid" and "redlichiid" faunal realms. They are both extinct near the end of the stage". It can be concluded, despite some uncertainty concerning their lower (Fallotaspis) and upper 
(Oryctocephalus indicus) limits, that Zone 0 can reasonably be considered to be comprised in the interval between the base of the Olenellid Superzone and the base of the $O$. indicus Biozone (Stage 3 and Stage 4 of the Series 2). Zone 0 could possibly extend to the top of the $O$. indicus Biozone, which is the base of Zone 1.

\subsection{Zone 1, Zone 2 and Zone 3}

It is difficult to correlate these three zones with the recent global stratigraphy due to many inaccuracies and different versions of their definition. However, there is no doubt that they generally are attributed to the Miaolingian in litteris, more or less the "middle Cambrian". The succession of the three biozones above each other has never been challenged, but their correlation with the chronostratigraphy has evolved and changed through advancing insights. To illustrate the different proposed hypotheses, Figure 2 shows the successive versions published by Vanguestaine and colleagues in chronological order, versus the biozonation with trilobites from the Miaolingian Series (Peng et al., 2020). The position of zones 1 to 3 is highly variable in the different publications, but has developed over time as more data became available for comparison and control, not just in Belgian successions but also elsewhere. It was not until the work of Vanguestaine \& Léonard (2005, fig. 8) in the Givonne Inlier that a more reliable succession emerged, even if it is still partly uncertain due to the absence of outcrops in some sections (see $\S 8.4 .1$ ). It can also be noted that the position of Zone $4 \mathrm{~b}$ is quite stable, unlike Zone $4 \mathrm{a}$ which is rarely observed (see $\S 5.3$ ).

It can be concluded, despite minor uncertainties, that (Fig. 2):

- Zone 1 can be correlated approximately with the trilobite biozones from the base of the Acadoparadoxides oelandicus Superzone to the base of the Ptychagnostus atavus Biozone.

- Zone 2 appears to be correlatable to the extension of the Adara alea acritarch Biozone (Martin \& Dean, 1988 in Newfoundland; Vanguestaine \& Léonard, 2005, fig. 7, Givonne Inlier), which corresponds to the trilobite biozones from a level in the upper Tomagnostus fissus Biozone to the lower Ptychagnostus punctuosus Biozone in Newfoundland (Martin \& Dean, 1988). This interval in turn correlates approximately with the Ptychagnostus atavus and $P$. punctuosus trilobite biozones (Hildenbrand et al., 2021, fig. 3).

- Zone 3 was rarely observed, as can be seen in Figure 2, and only in the Stavelot-Venn Inlier (Vanguestaine, 1986; 1992, fig. 5) and in the Givonne Inlier (Vanguestaine \& Léonard, 2005). From the correlation shown in Vanguestaine (1992, fig. 6), Zone 3 seemingly equates with a level within the interval from the base of the Goniagnostus nathorsti Biozone to about the upper part of Lejopyge laevigata Biozone (Fig. 2).

Accurate correlation of these three zones to the standard chronostratigraphy is particularly crucial (see $\S 8.2$ ). Indeed, Zone 3 and Zone $4 \mathrm{a}$ seem to be absent in the Rocroi Inlier (Vanguestaine, 1977, fig. 6, 1992, fig. 5).

\subsection{Zone $4 a$ and $4 b$}

Note that Zone $4 \mathrm{a}$ is rarely observed or cited, but could occupy the lower part of Zone $4 \mathrm{~b}$ or the upper part of Zone 3 (Vanguestaine \& Léonard, 2005). We can clearly question its existence as a useful biozone. Zone $4 \mathrm{~b}$ is well constrained by Vanguestaine (1992, figs 5, 6) and Ribecai \& Vanguestaine (1993, fig. 3), and can be correlated from about the upper part of

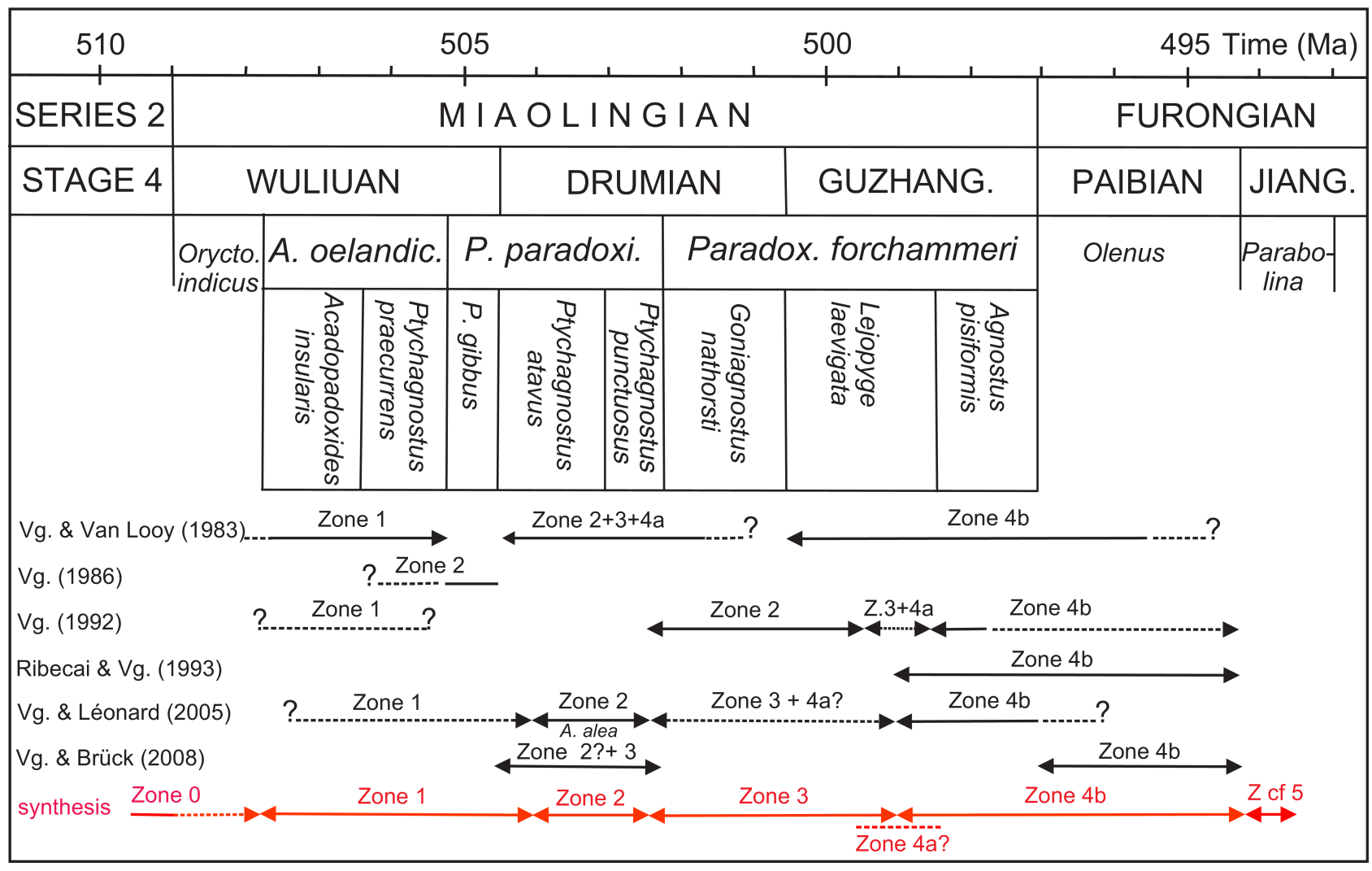

Figure 2. Stratigraphic scheme of the chronostratigraphy and the trilobites biostratigraphy from the Wuliuan to the Jiangshanian stages (Peng et al., 2020) against the different versions of the informal acritarch biozones published by Vanguestaine and co-workers (in chronological order). Our proposed synthesis of the acritarch biozones is in red. Vg. = Vanguestaine; Guzhang. = Guzhangian; Jiang. = Jiangshanian. 
L. laevigata trilobite Biozone to the top of the Olenus trilobite Biozone (Fig. 2).

\subsection{Zone cf 5 and Zone 5}

Contrary to the original definition by Vanguestaine (1986, p. 71), the Zone ef 5 lies just below Zone 5 (Vanguestaine, 1992, fig. 5). This short zone is intermediate in character between zones $4 \mathrm{~b}$ and 5 . Zone 5 is well defined and can be correlated from the Parabolina trilobite Biozone to the base of the Peltura trilobite Biozone (Vanguestaine, 1992, fig. 6; Ribecai \& Vanguestaine, 1993, fig. 3).

\subsection{Zone cf 6 and Zone 6}

Zone cf 6 lies just below Zone 6 (Vanguestaine, 1992, figs 5, 6). It is a short zone intermediate in character between zones 5 and 6 (Vanguestaine, 1992, fig. 5). Zone 6 is well constrained in Vanguestaine (1992, figs 5, 6) and Ribecai \& Vanguestaine (1993, fig. 3) and can be correlated with the middle of Peltura trilobite Biozone to the top of the Acerocarina trilobite Biozone. The latter is the highest trilobite biozone of the Cambrian (Stage 10 of the Furongian Series).

\subsection{Zone 7}

Zone 7 and the overlying zones are Ordovician and the acritarch biozones can be correlated with the graptolite biozonation of Avalonia (Goldman et al., 2020, fig. 20.4, column Baltica for the lower Tremadocian then column Britain and fig. 20.3, column Britain). Zone 7 was already observed in an early phase of the work of Vanguestaine $(1973,1974)$ in the Jalhay Fm (Sm1), the lower part of the Salm Group of the Stavelot-Venn Inlier. The Jalhay Fm consists of three members. Graptolites are abundant in the Solwaster Member (Mbr) (Sm1a) and rarer in the Spa Mbr (Sm1b), whereas acritarchs are present at the top of the Solwaster Mbr, abundant in the Spa Mbr and again only present in the upper part of the Lierneux Mbr (Sm1c) (Catot, 1991; 1992). Zone 7 is hence established in Stavelot-Venn Inlier from the base of the Solwaster Mbr to the top of the Spa Mbr.

This is confirmed by Wang \& Servais (2015, fig. 2) who reinvestigated the collections of graptolites from this formation preserved in Belgian museums. Based on the ranges of the lower Tremadocian graptolites (Cooper et al., 1998; 2004), the Solwaster Mbr (Sm1a) extends from the base of the Rhabdinopora praeparabola to the Rhabdinopora flabelliformis parabola graptolite biozones while $R$. flabelliformis flabelliformis, $R$. flabelliformis socialis and R. flabelliformis anglica biozones occur in a slightly higher part. The lower part of the Spa Mbr (Sm1b) shows the R. f. socialis and R. f. anglica graptolite biozones. The Solwaster Mbr hence can be attributed to the lower Tremadocian, in the time slice 1a (Webby et al., 2004), and the lower part of the Spa Mbr to the upper half of the same time slice 1a also from the lower Tremadocian (Wang \& Servais, 2015, fig. 2) (Fig. 3).

\subsection{Zone 8}

This poorly defined Zone 8 (Vanguestaine, 1974; 1992) has only recently been revised. Acritarchs from the "messaoudensistrifidum acritarch assemblage" observed in the upper part of the Lierneux Mbr (Sm1c) can be correlated with the upper Tremadocian (Servais \& Mette, 2000; Vanguestaine \& Servais, 2002; Breuer \& Vanguestaine, 2004). It therefore appears that the Jalhay $\mathrm{Fm}$ can be dated with most, if not all of the Tremadocian. The discovery of conodonts of the Parastodus proteus Biozone at the boundary between the Meuville and Les
Plattes members (Ottré Fm, Sm2) in the Lienne Syncline tentatively gives a latest Tremadocian age, although an early Floian age cannot be excluded (Vanguestaine et al., 2004). An early Floian age is more likely in the light of the biostratigraphical age of the Jalhay Fm which, as we have just seen, seems to occupy all the Tremadocian as well as the lithostratigraphic position where the conodont was found. Zone 8 can therefore be considered to occupy the upper part of the Tremadocian and extends into the lower part of the Ottré Fm to approximately the boundary between the Meuville and Les Plattes members (Fig. 3; Herbosch et al., 2016).

\subsection{Zone 9}

Zone 9 was added by Vanguestaine (1986) following the discovery of a new acritarch association in the Stavelot-Venn Inlier (upper Salmchâteau Mbr, Sm3b, Bihain Fm), top of the Salm Group. The same acritarch association was observed in the Vieux-Moulins de Thilay Fm of the Rocroi Inlier (Roche et al., 1986) which also forms the top of the Salm Group (Fig. 3). More recently Vanguestaine \& Wauthoz (2011) identified the acritarch biozone "Frankea hamata-Striatotheca rarrigulata" in Zone 9 from the lower and middle part of the Abbaye de Villers Fm of the Brabant Massif.

In the English Lake District, the Frankea hamataStriatotheca rarrigulata Biozone is situated in the same level with the Isograptus gibberulus and Aulograptus cucullus (formerly Didymograptus hirundo) graptolite biozones (Cooper \& Molyneux, 1990; Molyneux in Cooper et al., 2004). In the Brabant Massif, the Thyle valley section of the Abbaye de Villers Fm was sampled in collaboration with Michel Vanguestaine. Sample $89 / 7$ is located a few metres above the boundary with the underlying Chevlipont Fm (Vanguestaine \& Wauthoz, 2011). There is no fault between these two formations (geological map of Herbosch \& Lemonne, 2000), contrary to the Anthoine \& Anthoine's (1943) descriptions. On the other hand, an important stratigraphic hiatus is observed between the Chevlipont and Abbaye de Villers formations (e.g. Verniers et al., 2001). Although the boundary between these two formations is not visible in the Thyle valley due to an observation gap, we can assume, by comparison with the Wépion borehole, that the contact between the Chevlipont and Abbaye de Villers formations corresponds also to an unconformity. It was indeed demonstrated in the Wépion borehole (Condroz Inlier) that the top of the Chevlipont Fm corresponds to an unconformity (Graulich, 1961; Vanmeirhaeghe, 2006). Sample 89/7 contains only Striatotheca rarrigulata (Vanguestaine \& Wauthoz, 2011), which is one of the characteristic acritarchs of the Frankea hamata-Striatotheca rarrigulata assemblage observed in the remainder of the formation. We therefore suggest that the Abbaye de Villers Fm could be indirectly correlated by the acritarch biozones to the upper Dapingian and the lowermost Darriwilian.

In the uppermost parts of the Stavelot-Venn Inlier and Rocroi Inlier sedimentary record, the acritarch associations are similar, with in particular the presence of the three guide species of Zone 9 (Frankea sartbernardensis, Arkonia tenuata, Striatotheca principalis; Vanguestaine, 1986; Roche et al., 1986). The acritarch associations of Zone 9 can also be assigned to the Frankea hamata-Striatotheca rarrigulata Biozone, even if not all typical acritarch species are present. This is all the more likely as Servais et al. (2017), in a synthesis of the First Appearance Datum (FADs) of selected acritarch taxa from the Middle Ordovician, place the FAD of the genus Frankea in the upper part of the Dapingian (stage slice Dp3; Servais et al., 2017, fig. 4), that of the genus Arkonia in the first half of the Darriwilian (provisional stage slice Dw1). The presence of two 


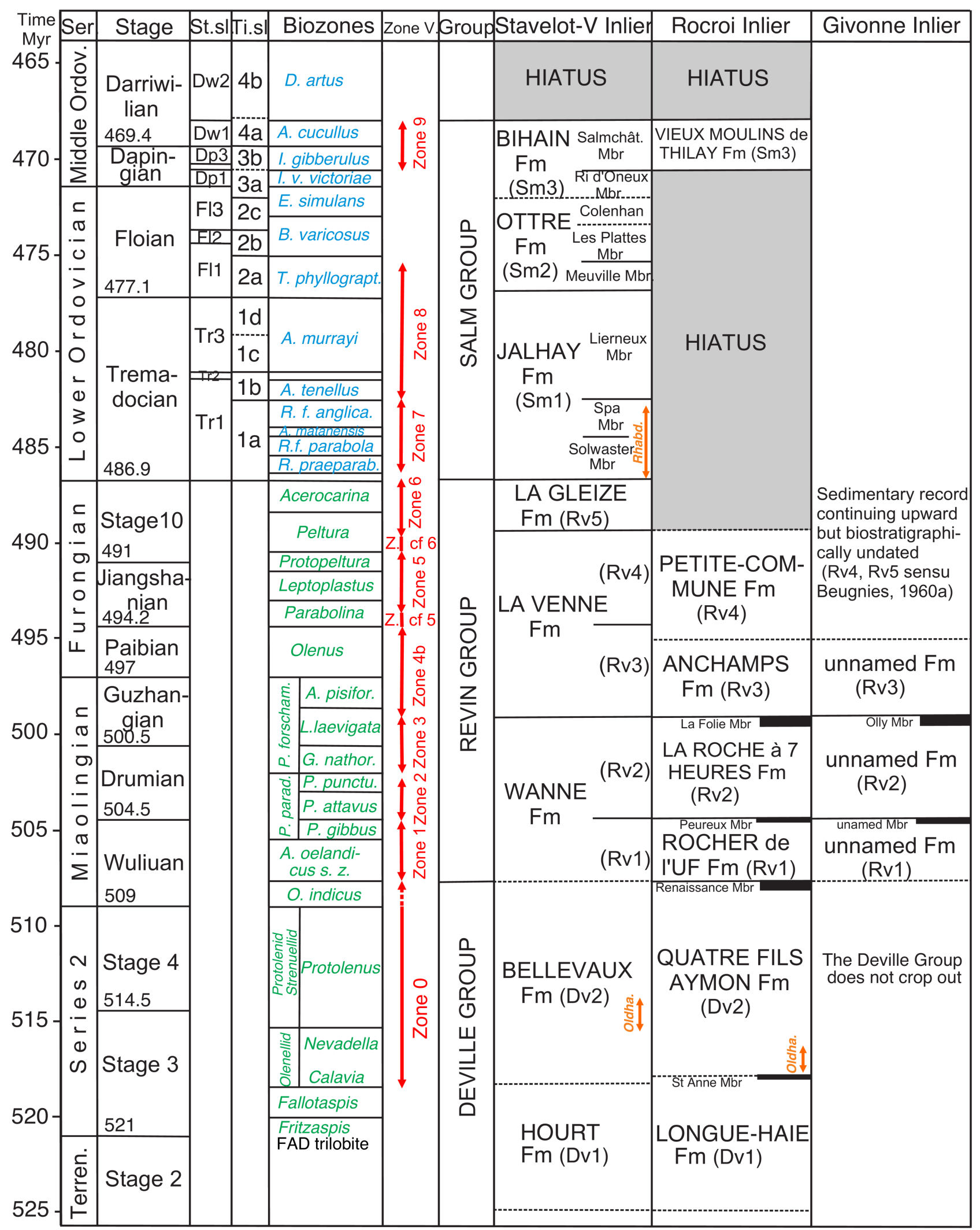

Figure 3. Chronostratigraphic position of the informal acritarch biozones of Vanguestaine reinterpreted in this study and the formation $\mathrm{s}$ of the Stavelot-Venn, Rocroi and Givonne inliers between the lower Cambrian and the Middle Ordovician. Trilobite biozones after Geyer \& Shergold (2000) and Peng et al. (2020). Graptolite biozones after Goldman et al. (2020, figs 20.3 and 20.4). Chronostratigraphy after Gradstein et al. (2020). Time slices after Webby et al. (2004) and stage slices after Bergström et al. (2009). Dotted line: boundary between formations less precise. Zone V. = reinterpreted Vanguestaine's acritarch biozones; st. sl. = stage slices; ti. sl. = time slices; Rhabd.$=$ Rhabdinopora Oldha.$=$ Oldhamia; Salmchât. = Salmchâteau. 
of these three important genera in Zone 9 corresponds to the I. gibberulus and A. cucullus biozones, from the upper Dapingian to the lowermost Darriwilian.

With the above, we have established that the Abbaye de Villers Fm of the Brabant Massif, the Salmchâteau Mbr (Sm3b) of the Stavelot-Venn Inlier and the Vieux Moulins de Thilay Fm (Sm3) of the Rocroi Inlier belong to the same acritarch Zone 9 and therefore belong to the same time interval (Figs 3, 5). This is an important conclusion because in the Brabant Massif it corresponds to a resumption of sedimentation after a long stratigraphic hiatus and in the two other cases it is the end of sedimentation in the Ardenne inliers. This paradox, known for a long time but never discussed nor explained, is not a simple coincidence and requires a better explanation (see $\S 9.3$ ).

\section{Chronostratigraphy of the formations of the Brabant Massif}

The most recent stratigraphic description of the Cambrian and Ordovician formations of the Brabant Massif was published by Herbosch \& Verniers $(2013,2014)$. This chapter will only make minor adjustments resulting from the advancement of global stratigraphy (Gradstein et al., 2020). It will take into account the new stratigraphic advances since the last syntheses and will explain the choices and decisions, including those that are less well supported scientifically.

\subsection{The Blanmont Formation}

The Blanmont Fm is the oldest formation cropping out in the Brabant Massif (Herbosch et al., 2008). Malaise (1900, 1901) mentioned the presence of the ichnofossil Oldhamia in slates interbedded in quartzites of former quarries in the Orne valley (Mont-St-Guibert). The present-day outcrops, much less numerous, do not allow to confirm the presence of this ichnofossil. Moreover, these old descriptions are not accurate enough to identify in which part of the formation Oldhamia was found.

In spite of the absence of other fossils, only an approximate age range can be assigned to the Blanmont $\mathrm{Fm}$ by indirect arguments and comparison with the formations of the Deville Group of the Ardenne inliers. First, the Blanmont Fm is lithologically very similar to the essentially quartzitic formations of Hourt (Stavelot-Venn Inlier) and Longue-Haie (Rocroi Inlier) formations, except for the absence of Oldhamia in the latter two. In contrast, Oldhamia is present in the three members of the Tubize Fm (Brabant Massif), in the middle part of the Bellevaux Fm (Stavelot-Venn Inlier) and at the base of the Quatre Fils Aymon Fm (Rocroi Inlier; Fig. 4). The Oisquercq, Quatre Fils Aymon and Bellevaux formations can be correlated, via biostratigraphy of acritarchs, to Zone 0 (e.g. Vanguestaine, 1992). This allows to date these formations from the middle of Stage 3 to the lower part of the Wuliuan Stage of the Series 2 (see $\S 5.1$ ). Consequently, the top of the Hourt and the Longue-Haie formations is placed at the lower limit of Zone 0 (Fig. 4), whereas the upper limit of the Blanmont Fm is placed somewhat higher as it contains Oldhamia. The lower limit of these three formations is placed well below the appearance of Oldhamia (about the base of Stage 3 in Herbosch \& Verniers, 2011, fig. 2). In consequence, the Blanmont Fm extends approximately from about the middle of Stage 2 to the middle of Stage 3 (Fig. 4).

\subsection{The Tubize and Oisquercq formations}

As we have just seen, the Tubize Fm extends from about the middle of Stage 3 (in the Olenellid Superzone) to the lower half of Stage 4 (Fig. 4). The Oisquercq Fm, assigned only in two boreholes to Zone 0 (Vanguestaine, 1992), extends from about the lower half of Stage 4 to the base of the Wuliuan (Figs 4, 5).

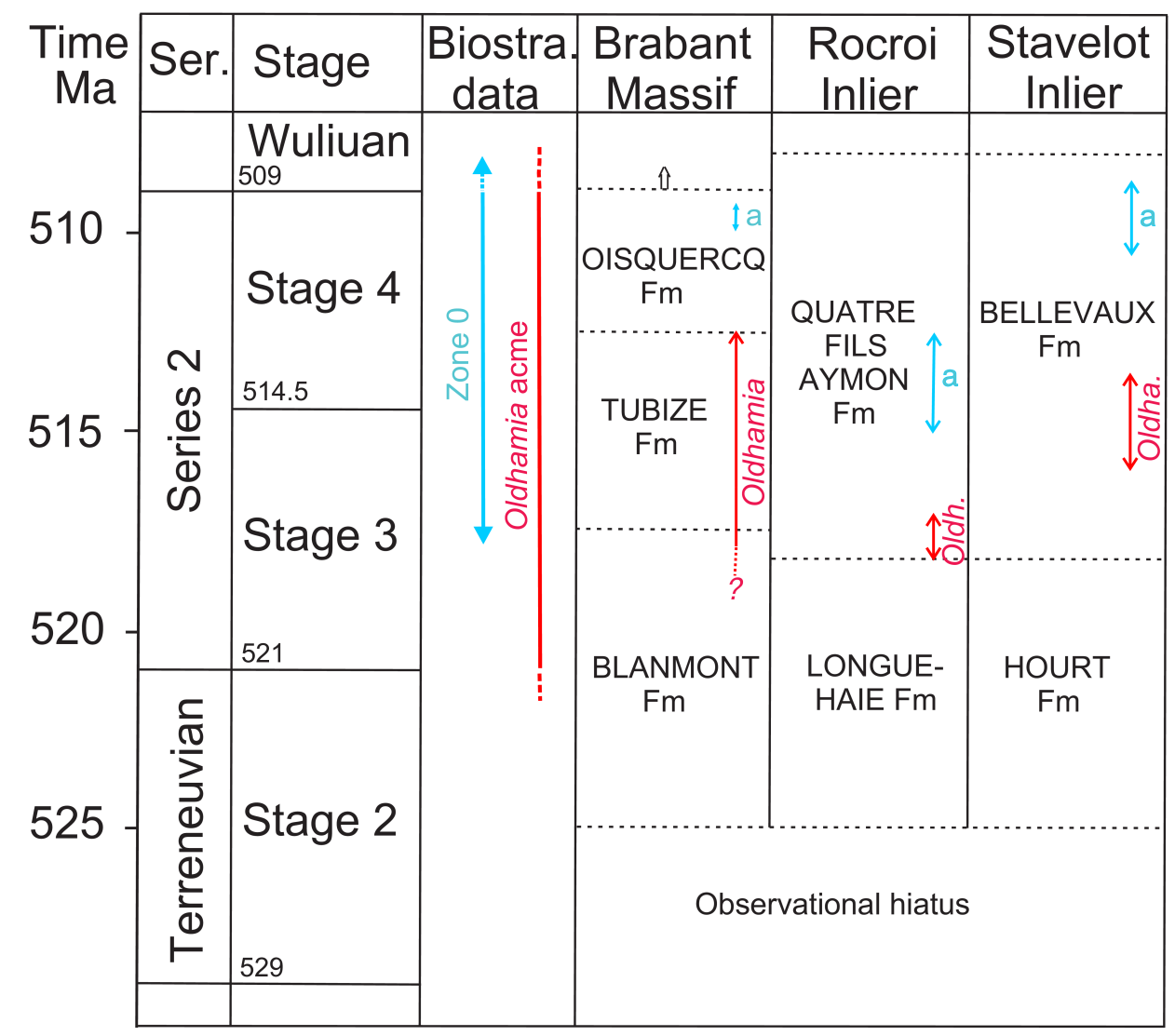

Figure 4. Chronostratigraphic position of the formations belonging to Terreneuvian and Series 2 (former lower Cambrian) in the Brabant Massif, the Stavelot-Venn and Rocroi inliers according to the Cambrian stages as reviewed by Peng et al. (2020). Biostratigraphical data, as the acritarch biozone Zone 0 (see $\S 5.1$ ) and the acme of the ichnofossil Oldhamia (Herbosch \& Verniers, 2011) are added as well as the observed presence of Oldhamia and acritarchs (letter a) in the formations. Ser. = Series; Oldh.$=$ Oldhamia . 


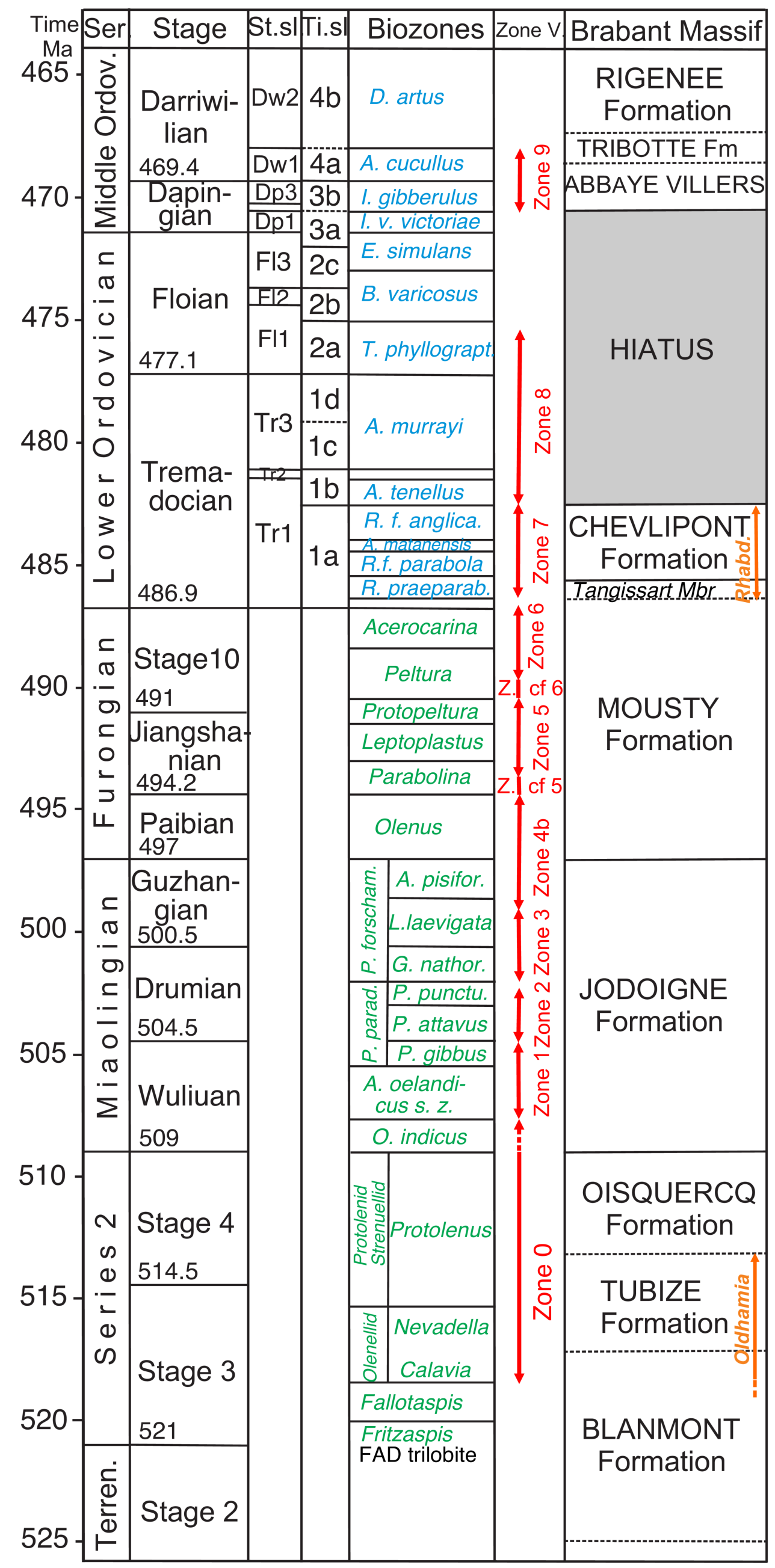

Figure 5. Chronostratigraphic position of the informal acritarch biozones of Vanguestaine reinterpreted in this study and the formations of the Brabant Massif between the lower Cambrian and the Middle Ordovician. Trilobite biozones after Geyer \& Shergold (2000) and Peng et al. (2020). Graptolite biozones after Goldman et al. (2020, figs 20.3 and 20.4) and chronostratigraphy after Gradstein et al. (2020). Time slices after Webby et al. (2004) and stage slices after Bergström et al. (2009). Dotted line: boundary between formations less precise; st. sl. = stage slices; ti. sl. = time slices; Zone V. = reinterpreted Vanguestaine's acritarch biozones; Rhabd. = Rhabdinopora. 


\subsection{The Jodoigne Formation}

This formation has so far not yielded any macro- or microfossils, despite numerous attempts with Michel Vanguestaine during the survey of the Jodoigne-Jauche map (Herbosch et al., 2019). Based on detailed mapping, lithological and sedimentological observations, combined with an evaluation of existing biostratigraphic data of the neighbouring formations and the few boreholes, Herbosch et al. (2008) suggested that this formation belongs to the Miaolingian Series (former Middle Cambrian). Important evidence is found in the Leuven borehole (89E01), dated by acritarchs and correlated with the lower part of the middle Cambrian (Vanguestaine, 1974; 1992, fig. 8). This borehole and also the Heverlee borehole (89E363) show a typical turbiditic facies allowing these two borehole successions to be reassigned to the Jodoigne Fm rather than to the Mousty Fm, to which they were assigned previously (e.g. De Vos et al., 1993). The Jodoigne Fm occupies the interval between the underlying Oisquercq Fm and the succeeding Mousty Fm, i.e. the entire Miaolingian Series (Fig. 5).

\subsection{The Mousty Formation}

The lower and middle parts of the formation were dated by acritarchs only in boreholes (Vanguestaine, 1974; 1992) indicating the lower and middle parts of the upper Cambrian for the Eine (84E1372) and the Vollezele (100E010) boreholes (Vanguestaine et al., 1989; Vanguestaine, 1992, fig. 8). In the Cortil-Noirmont (130W539) borehole, probably located at the base of the formation, the predominance of the Prismatomorphitae (Timofeevia-Cristallinium-Vulcanisphaera) over the Diacromorphitae (Acanthodiacrodium-ArbusculidiumLadogella) is characteristic of the upper Cambrian. This together with the presence of several specimens of ?Lusatia sp. as in the upper Cambrian from Montcornet-en-Ardennes (Rocroi Inlier; Ribecai \& Vanguestaine, 1993, Zone cf 6) and the absence of Tremadocian markers led to the interpretation of an upper Cambrian age (Vanguestaine, pers. comm., 1998; Vanguestaine in Delcambre \& Pingot, 2002, p. 17).

In the uppermost member of the Mousty Fm, the Tangissart $\mathrm{Mbr}$, the discovery of the graptolite Rhabdinopora flabelliformis ssp. socialis (between Laroche and Faux; Lecompte, 1948; 1949) proves its lowest Tremadocian age. Recently, Wang \& Servais $(2015$, figs 2,3) have taken up the exhaustive study of the graptolite $R$. flabelliformis of the Brabant Massif and the Wépion borehole (Condroz Inlier) stored in Belgian collections. They have shown that the graptolites of this upper member belong to the $R$. praeparabola Biozone which is found at the extreme base of the Tremadocian Stage, more precisely the lower part of the time slice 1a of Webby et al. (2004), which extends precisely from 486.85 to c. $485.5 \mathrm{Ma}$ using the graptolite biozonation of Goldman et al. (2020, fig. 20.4, column Baltica).

In conclusion, the Mousty Fm extends from the base of the Furongian Series to the base of the Tremadocian. It therefore includes the Paibian, Jiangshanian and Stage 10 as well as the basal $1 \mathrm{Ma}$ or so of the Tremadocian (Fig. 5).

\subsection{The Chevlipont Formation}

The lower half of the formation contains the dendroid graptolites $R$. flabelliformis ssp. socialis and typica (Lecompte, 1948; 1949) and also very well preserved acritarchs (Martin, $1969 \mathrm{a}, \mathrm{b} ; 1$ 1976) that indicate the lower Tremadocian. In the upper part of the formation, in Bois de l'Hermitage, Lecompte (1949) described a clearly different subspecies $R$. flabelliformis aff. norvegica which indicates a higher level. Wang \& Servais (2015, fig. 2) showed that graptolites collected in the Chevlipont Fm (including those from the Wépion borehole) belong to the Rhabdinopora praeparabola, $R . f$. parabola, Anisograptus matanensis and $R$. f. anglica biozones spanning the time slice 1a of Webby et al. (2004) (Fig. 5). In Goldmann et al. (2020, fig. 20.4, Baltica column) the top of the $R$. anglica Biozone is dated at $482.7 \mathrm{Ma}$ which, in the absence of other palaeontological data, can be considered as the age of the top of the Chevlipont Fm.

Vanguestaine (2008, p. 13) placed the acritarchs from the Chevlipont Fm (Sennette valley), in the Acanthodiacrodium angustum assemblage. In that paper Acanthodiacrodium spp., Cymatiogalea spp., and Stelliferidium spp. are commonly found, Vulcanisphera flagellum is present, and Acanthodiacrodium ubuii is probably also present but poorly preserved. This assemblage is similar to that observed in Chevlipont Fm from the Thyle river and in the Lessines (Brabant Massif) and Wépion (Condroz Inlier) boreholes, and also in the Solwaster and Spa members of the Jalhay Fm (Stavelot-Venn Inlier). An early Tremadocian age is therefore probable, but more accurate identification of $A$. ubuii would be needed to confirm this, as the species is restricted to the lower part of the Tremadocian (Rasul \& Downie, 1974).

In conclusion, the age of the Chevlipont Formation is early Tremadocian (485.5-c. 482.7 Ma) except the lowermost basal Tremadocian which belongs to the Mousty Fm (Fig. 5).

\subsection{Hiatus}

There is then a stratigraphic hiatus of about $15 \mathrm{Ma}$ which corresponds to an emersion of the Brabant Massif coincident with the drifting of the Avalonia microcontinent away from Gondwana and the opening of the Rheic Ocean (see arguments in Cocks \& Torsvik, 2002; 2005; 2021; Verniers et al., 2002; Linnemann et al., 2012; Herbosch et al., 2016).

\subsection{The Abbaye de Villers Formation}

Of the chitinozoans observed in the middle part of the formation (according to the map of Herbosch \& Lemonne, 2000) Eremochitina brevis is the most characteristic (Samuelsson \& Verniers, 2000). It is the eponymous species of the E. brevis Biozone in the upper part of the Floian Stage of "North" Gondwana (Goldman et al., 2020, table 20.4). The species Lagenochitina obeligis, Euconochitina vulgaris and Cyathochitina cf. dispar, found in the upper part of the formation (Dyle and Senne basins), are less indicative but suggest an age between mid Dapingian and mid Darriwilian (Samuelsson \& Verniers, 2000). Martin (1976), Vanguestaine et al. (1989) and Vanguestaine (in André et al., 1991) reported the presence of the acritarchs Frankea sartbernardensis var. A., Adorfia firma, and Frankea hamata var. A. The genus Frankea is considered to have its first appearance in the upper Dapingian (stage slice Dp3; Servais et al., 2017).

As shown in $\S 5.8$, the acritarchs of the entire Abbaye de Villers Fm can be attributed to the Frankea hamata-Striatotheca rarrigulata assemblage (Vanguestaine \& Wauthoz, 2011) which are also found in the English Lake District in the I. gibberulus and $A$. cucullus graptolite biozones. Considering the latter as the most reliable estimate and the age of the overlying Tribotte Fm (see $\S 6.8$ ), the Abbaye de Villers Fm can be located indirectly from the upper Dapingian to the lower Darriwilian (Fig. 5).

\subsection{The Tribotte Formation}

A poor chitinozoan assemblage containing Euconochitina vulgaris indicates an upper Floian to lower Darriwilian 
(Verniers et al., 1999; Samuelsson \& Verniers, 2000). The assemblage of acritarchs recorded by Vanguestaine \& Wauthoz (2011) from the lower part of the Tribotte Fm in the Dyle basin is very similar to that of the Abbaye de Villers Fm and belongs also to the Frankea hamata-Striatotheca rarrigulata Biozone. The uppermost part of the formation yields Frankea sartbernardensis and possibly Vogtlandia multiradialis possibly indicating an age from the lower half of the Darriwilian (Vanguestaine \& Wauthoz, 2011, fig. 4). In conclusion and taking into consideration the age of the Abbaye de Villers and Rigenée formations, the Tribotte Fm encompasses a small time interval in the lower Darriwilian corresponding approximately to the upper part of the A. cucullus Biozone to the lower Didyimograptus artus Biozone (Fig. 5).

\subsection{The Rigenée Formation}

Graptolites from the lithological "unit D" in the Sennette valley, now attributed to the Rigenée Fm, were placed by Martin \& Rickards (1979) at the top of the Didymograptus bifidus Biozone (now D. artus Biozone). A study of old and new collections from the $\mathrm{km} 39.775$ canal section by Maletz \& Servais (1998, fig. 4) shows that the graptolites are too poorly preserved to differentiate between the $D$. artus and the $D$. murchisoni biozones. Servais $(1991 ; 1993)$ observed the successive appearances of Frankea sartbernardensis, Arkonia virgata and Frankea hamulata in the lowermost, lower and middle parts of the formation, the last two species being Llandvirn (upper Darriwilian) markers and not recorded from Arenig (Floian, Dapingian and lower Darriwilian) strata. Vanguestaine \& Wauthoz (2011, fig. 4), taking all available data into account, placed the Arenig-Llanvirn boundary (mid Darriwilian) within the Rigenée Fm (at the appearance of either A. virgata or $F$. hamulata). A poor assemblage of chitinozoans with Lagenochitina obeligis and Cyathochitina calix indicates most probably a Darriwilian age (Molyneux, com. pers., 2021). It can be added that the base of the overlying formation, the Ittre Fm, contains chitinozoans belonging to the late Sandbian to early Katian (Vanmeirhaeghe, 2006).

Taking into account all these results, particularly the stratigraphic position of the underlying Tribotte Fm and the overlying Ittre Fm, the Rigenée Fm can be approximately located from the lower to the upper Darriwilian, or even the mid Sandbian (Fig. 5).

The sedimentary record of the Brabant Massif continues well above the Rigenée Fm until the end of the Silurian. The revision of the remainder formations is not discussed here because the sedimentary record in the Ardenne inliers ends in the Middle Ordovician.

\section{Chronostratigraphy of the formations of the Stavelot-Venn Inlier}

The most recently established stratigraphy of the CambrianOrdovician in the Stavelot-Venn Inlier was established by Herbosch et al. (2020, fig. 3). As such, only minor adjustments are made here, following the advancement of the global stratigraphy (Gradstein et al., 2020). But as with the Brabant Massif, this chapter will take into account new stratigraphic advances since the last syntheses and will explain choices and decisions, including those that are less well supported scientifically.

\subsection{The Hourt Formation}

The Hourt Fm is the oldest formation cropping out in the Stavelot-Venn Inlier (von Hoegen et al., 1985; Geukens, 2008).
Despite the absence of macro- and microfossils, an approximate age can be assigned by comparison with the lithologically very similar Blanmont (Brabant Massif) and Longue-Haie (Rocroi Inlier) formations. As a consequence of the reasoning in $\S 6.1$ (Fig. 4), the top of the Hourt Fm is placed at the lower limit of Zone 0 . Its lower limit is placed well below the appearance of the Oldhamia ichnofossil (Herbosch \& Verniers, 2011), i.e. around $525 \mathrm{Ma}$. The Hourt Fm thus approximately comprises the interval between the upper part of Stage 2 and the middle of Stage 3 (Figs 3, 4).

\subsection{The Bellevaux Formation}

The ichnofossil Oldhamia was discovered at the end of the 19th century (Malaise, 1874; 1876; 1878) in approximately the middle part of the formation (Figs 2, 3). The uppermost part of the formation was dated by acritarchs from Zone 0 (Vanguestaine, 1974; 1992). The Bellevaux Fm thus extends between the middle of Stage 3 to the top of Stage 4 (Fig. 3). However, it is possible that its upper limit reaches the top of the O. indicus Biozone (see $\S 5.1$ ).

\subsection{The Wanne Formation}

The Wanne Fm consists of two unnamed members, Rv1 and Rv2 (former nomenclature of Geukens, 1949; Beugnies, 1960b). Member Rv1 contains acritarchs from Zone 1 (Vanguestaine, 1977, fig. 3; 1992, fig. 5) which is correlated from the top of the O. indicus to the top of the Ptychagnostus gibbus biozones. Member Rv2 contains acritarchs from Zone 2 and Zone 3 (Vanguestaine, 1977, fig. 3; 1992, fig. 5). It thus extends from the lowest part of the Wuliuan Stage to the middle part of the Guzhangian Stage, i.e. a large part of the Miaolingian Series (Fig. 3).

\subsection{The La Venne Formation}

This formation also consists of two unnamed members, Rv3 and Rv4 of the former nomenclature (Geukens, 1949; Beugnies, 1960b). Member Rv3 contains acritarchs from Zone 4a in its lower part and Zone 4b in its upper part (Vanguestaine, 1977, fig. 3; 1992, fig. 5; Ribecai \& Vanguestaine, 1993, figs 2, 3). These zones are correlated from the upper part of the $L$. laevigata Biozone to the top of the Olenus Biozone. The upper part of Member Rv4 contains acritarchs from Zone 5 (same references), which correlates from the upper half of the Parabolina Biozone to the base of Peltura Biozone. Taking into account the lower limit of the La Gleize Fm that follows it, Zone cf 6 must be added, the top of which is in the middle of the Peltura Biozone (Ribecai \& Vanguestaine, 1993, figs 2, 3).

The La Venne Fm thus occupies the upper half of the Guzhangian, the Paibian, the Jiangshanian stages and the lower half of Stage 10, which is a large part of the Furongian Series (Fig. 3).

\subsection{The La Gleize Formation}

The La Gleize Fm contains acritarchs of Zone 6, which has been correlated with trilobite biozonation from the middle of the Peltura Biozone to the top of the Acerocarina Biozone (Vanguestaine, 1992). It thus extends over most of Stage 10 and its top coincides with the top of the Cambrian (Fig. 3).

\subsection{The Jalhay Formation}

As mentioned above, the formation consists of three members. In the two lower ones (Solwaster and Spa members) acritarchs 
of Zone 7 are present. Graptolites are also present and range from the $R$. praeparabola to $R$. flabelliformis anglica biozones (Wang \& Servais, 2015). Recently, Candela et al. (2021) described graptolites identified as $R$. flabelliformis socialis and $? R$. praeparabola in the lower part of the Solwaster Mbr of the Jalhay Fm which confirms the early Tremadocian age (time slice 1a) of this member, already found by Wang \& Servais (2015). The upper Lierneux Mbr contains acritarchs of the higher Zone 8 which is correlated with the upper part of the Tremadocian (see $\S 5.7$ ). Hence, the Jalhay Fm spans over the whole Tremadocian (Fig. 3).

\subsection{The Ottré Formation}

The Ottré Fm contains three members that are completely devoid of microfossils due to their highly oxidizing depositional environment (Herbosch et al., 2016). But the discovery of conodonts of the Parastodus proteus Biozone at the boundary between the Meuville and Les Plattes members in the Lienne Syncline (Vanguestaine et al., 2004) allows to tentatively attribute this level to the latest Tremadocian without excluding the lower Floian. An early Floian age is more likely in the light of the upper Tremadocian age of the underlying Jalhay Fm. The upper limit of the Ottré Fm is uncertain, and is placed more or less arbitrarily in the upper part of the Floian Stage. Thus the Ottré Fm extends from the top of the Tremadocian to approximately the upper part of the Floian (Fig. 3).

\subsection{The Bihain Formation}

The Bihain Fm comprises two members. The upper one, the Salmchâteau Mbr, contains acritarchs of Zone 9 that have been correlated with the I. gibberulus to A. cucullus graptolite biozones (Vanguestaine, 1986; 1992; Servais, pers. comm., 2005). The Bihain Fm extends from approximately the uppermost part of the Floian to the lowermost Darriwilian (Fig. 3).

The sedimentary record of the Stavelot-Venn Inlier ends with the upper member of the Bihain Fm. The stratigraphic hiatus that follows goes as high as the uppermost Pridoli (c. 418 $\mathrm{Ma}$, Silurian) with the "Gedinnian transgression" underlined by the conglomerate of the Ardennian unconformity.

\section{Chronostratigraphic position of the formations of the Rocroi and Givonne inliers}

The Rocroi and Givonne inliers are considered together, given the important similarity of the sedimentary records of the Revin Group (the Deville Group is not cropping out at Givonne) in these two units. Furthermore, it would not have been possible to understand the succession of informal biozones in the Rocroi Inlier without the biostratigraphic investigations carried out in the Givonne Inlier, especially the most recent ones (Vanguestaine, 1977; Léonard, 2004; Vanguestaine \& Léonard, 2005).

\subsection{Palaeogeographical and tectonic relationships between these two inliers}

There is few literatures on the palaeogeographic and tectonic relationship between these two nearby inliers. However, Beugnies (1960a) emphasised on numerous occasions the strong lithological similarities between their constituent formations, in particular with regard to the marker levels constituted by the roofing slate seams (i.e. Beugnies, 1960a, 1960b). These two Cambrian inliers have tectonic structures that are globally oriented E-W (e.g. Beugnies, 1960a; 1963; Bélanger, 1998) and their extremities are only about $15 \mathrm{~km}$ apart. An N-S section parallel to the Meuse river (Lacquement, 2001, fig. 157D; Sintubin et al., 2009, figs 2, 3) shows that the Givonne Anticline is thrusted to the N onto the Neufchâteau Synclinorium via the Herbeumont Fault. This thrust, whose throw is in the order of $2500 \mathrm{~m}$ (Asselberghs, 1946), brings up a deeper part of the Rocroi Inlier near the southern edge of the Givonne Inlier (Fig. 6). These observations suggest that these two nearby but currently distinct inliers were part of the same sedimentation basin and were separated at the time of their deposition by only a few tens of $\mathrm{km}$, at the very most $100 \mathrm{~km}$. This conclusion is important for understanding the lithostratigraphic relationships between these two nearby inliers.

\subsection{Contrasting presence of acritarch Zone 3 and Zone $4 a$ in the Givonne Inlier and their absence in the Rocroi Inlier}

In his review paper, Vanguestaine (1992, fig. 5) emphasised several times the absence of Zone 3 and Zone 4a in the Rocroi Inlier and the same article suggested the occurrence of an important stratigraphic gap. This suggestion gives rise to two remarks:

(1) Zone 3 shows a duration of approximately $3 \mathrm{Ma}$ (see $\S$ 5.2; Fig. 3) and we have argued above that the poorly defined Zone $4 \mathrm{a}$ can no longer be proven to exist (see $\S 5.3$ ). This stratigraphic or observational gap is therefore not a very large one.

(2) the Rocher de l'Uf section at Fumay, where Vanguestaine (1977, fig. 4) sampled, is marked by the Rocher de l'Uf Fault which, according to Beugnies (1962, p. 22-23), is an overthrust fault that removes three quarters of the Roche à

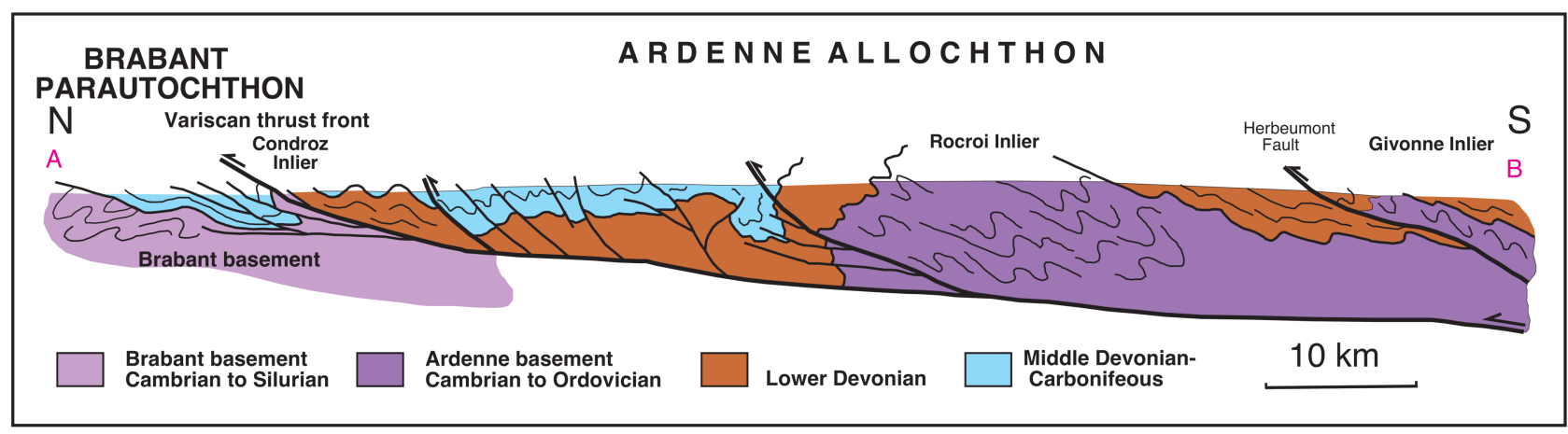

Figure 6. Simplified cross-section of Variscan foreland fold-and-thrust belt in the Ardenne from the Brabant basement in the $\mathrm{N}$ to the Rocroi and Givonne inliers in the S. See Fig. 1 for the location of the section. Modified from Sintubin et al. (2009). 
Sept Heures Fm. In consequence, it might be likely that a part of the strata assigned to Zone 3 have been removed by the Rocher de l'Uf Fault.

In addition, Zone 3 was identified in Givonne Inlier in three sections: Moulin Chicot (Vanguestaine, 1977, fig. 8), ClaireTerne de la Borne and Falizette (Vanguestaine \& Léonard, 2005, fig. 3). However, we have just seen that Givonne Inlier is probably a thrusted part of the Rocroi Inlier and that, consequently, the distance of their depositional environment was relatively small, especially as it is a deep depositional basin. If Zone 3 is present in the Givonne Inlier, then it should also be present in the Rocroi Inlier and there would be no stratigraphic gap in the Rocroi Inlier. I am well aware that this is a working conclusion that would require further biostratigraphic investigations to be confirmed.

\subsection{Chronostratigraphy of the formations of the Rocroi Inlier}

\subsubsection{The Longue-Haie Formation (Dv1)}

The Longue-Haie Fm is the oldest formation cropping out in the Rocroi Inlier (Beugnies, 1963). No macro- or microfossils have been observed. Its uppermost part shows a roofing slate seam, the St Anne Mbr, 4 to $7 \mathrm{~m}$ thick. Despite the absence of fossils, an approximate age can tentatively be attributed to it by comparison with the Blanmont (Brabant Massif) and Hourt (Stavelot-Venn Inlier) formations which are lithologically very similar. As a consequence of the reasoning in $\S 6.1$ (Fig. 4) the top of the Longue-Haie Fm is placed at the lower limit of Zone 0 . Its lower boundary is positioned well below the appearance of the Oldhamia ichnofossil (Herbosch \& Verniers, 2011), around $525 \mathrm{Ma}$. The Longue-Haie Fm is approximately and tentatively placed between the upper half of Stage 2 and the lower half of Stage 3 (base of the Olenellid Superzone) (Fig. 3).

\subsubsection{The Quatre Fils Aymon Formation (Dv2)}

In the $\mathrm{N}$ of the inlier (between Haybes and Fumay) Oldhamia was described in the lower 15-20 $\mathrm{m}$ of the formation (Beugnies, 1963 , p. 29). Its middle part contained acritarchs from Zone 0 (Vanguestaine, 1977, p. 254; 1992, fig. 5). Its upper part shows a thick $(10-25 \mathrm{~m})$ roofing slate seam, the Renaissance Mbr, exploited in the past. The Quatre Fils Aymon Fm is thus approximately located between the lower half of Stage 3 and the lower part of the Wuliuan Stage. However, it is tentative to suggest that its upper limit reaches the top of the $O$. indicus Biozone (Fig. 3).

\subsubsection{The Rocher de l'Uf Formation (Rv1)}

In the Rocher de l'Uf section at Fumay this formation is assigned to Zone 1 (Vanguestaine, 1977, figs 4, 6). The uppermost part of the formation shows a thin $(3-5 \mathrm{~m})$ roofing slate seam called the Peureux Mbr (Rv1b). The Rocher de l'Uf Fm includes most of the upper part of the Wuliuan Stage (Fig. 3).

\subsubsection{The La Roche à Sept Heures Formation (Rv2)}

In the Rocher de l'Uf section at Fumay this formation contains acritarchs from Zone 2 (Vanguestaine, 1977, figs 4, 6). However, as there are doubts about the continuity of this section (see discussion $\S 8.2$ ) and as Zone 3 is observed in the Givonne Inlier, the assumption that the La Roche à Sept Heures Fm covers the whole of the chronostratigraphic interval from the Drumian to the middle part of the Guzhangian seems reasonable. The upper part of the formation shows a thick (10
$30 \mathrm{~m}$ ) roofing slate seam called La Folie Mbr (Rv2b). I would therefore consider as a working hypothesis that the La Roche à Sept Heures Fm lies between the base of the Drumian and the middle of the Guzhangian (both Miaolingian) (Fig. 3).

\subsubsection{The Anchamps Formation (Rv3)}

In the Rocher de l'Uf section at Fumay this formation contains acritarchs from Zone 4b (Vanguestaine, 1977, figs 4, 6; Vanguestaine, 1992, fig. 5). By correlation, as explained above, the Anchamps Fm can indirectly be dated from the middle of the Guzhangian (Miaolingian) to the upper part of the Paibian (Furongian) (Fig. 3).

\subsubsection{The Petite-Commune Formation (Rv4)}

This formation contains acritarchs from the upper part of Zone $4 \mathrm{~b}$ to the top of Zone cf 6, with in between Zone cf 5 and Zone 5 (Meilliez \& Vanguestaine, 1983; Vanguestaine, 1992, fig. 5; Ribecai \& Vanguestaine, 1993, figs 2, 3). The Petite-Commune Fm is hence indirectly dated from the upper part of the Paibian to the lower part of Stage 10 (both Furongian) (Fig. 3).

\subsubsection{Stratigraphic hiatus}

Above the previous formations, there is a long stratigraphic hiatus of about $19 \mathrm{Ma}$. It could be shorter if the discovery of the Rhabdinopora graptolite, reported by Malaise (1878) in the Rocroi Inlier, was confirmed, which is nevertheless unlikely for Beugnies (1963). This hiatus corresponds broadly to that observed in the Brabant Massif, although it is slightly longer (19 Ma vs $15 \mathrm{Ma}$; Figs 3, 5). In comparison with the Brabant Massif, it is tempting to attribute also this hiatus to the drifting of the Avalonia microcontinent away from Gondwana together with the opening of the Rheic Ocean (Cocks \& Torsvik, 2002; 2005; Verniers et al., 2002; Herbosch et al., 2020).

\subsubsection{The Vieux Moulins de Thilay Formation (former Rv5, now Sm3)}

This formation, which was defined by Beugnies (1963) as the top of the Revin Group (Rv5), was redefined as belonging to the Salm Group by Geukens (1981) on a lithostratigraphic basis. This hypothesis was confirmed by Roche et al. (1986) who found an association of acritarchs typical of Zone 9. This allowed to date indirectly the Vieux Moulins de Thilay Fm. to the uppermost Dapingian and lowermost Darriwilian. It means that the formation falls within the same range as the Salmchâteau Mbr of the Bihain Fm (Stavelot-Venn Inlier) and the Abbaye de Villers Fm (Brabant Massif) (see discussion $\S 5.8$; Figs 3,5 ).

\subsection{Chronostratigraphy of the formations of the Givonne Inlier}

\subsubsection{Introduction}

For Beugnies (1960a; 1962) the Givonne Inlier shows only the Rv2 to Rv4 formations belonging to the Revin Group, but he wrote that the Salm Group could also be represented by the Pourru-aux-Bois Fm (Rv5). The latter formation has not yet been dated, so the hypothesis remains open. The biostratigraphic investigations of Vanguestaine (1977) and Vanguestaine \& Léonard (2005, fig. 3) were carried out in the vicinity of Bosséval-et-Briancourt, the less metamorphic western end of the Givonne Inlier. There are two N-S oriented sections: the first goes from the Ri de la Claire to the Ri du Terne de la Borne for $1400 \mathrm{~m}$, the second, more to the SE, follows the $\mathrm{Ri}$ des 
Falizettes for $800 \mathrm{~m}$ (op. cit., 2005, fig. 3). These two sections contain some observation gaps.

As a result of their field work and biostratigraphic study, Vanguestaine \& Léonard (2005) concluded that the lithostratigraphic succession proposed by Beugnies (1962, fig. 5, p. 74) for these sections, from bottom to top: La Chapelle Fm (Rv2) - Illy Fm (Rv3) - Sautou Fm (Rv4), was incorrect. Indeed, most of the Sautou Fm, in its type locality, is older than the La Chapelle Fm. It also appears, from the biostratigraphy, that the Illy Fm includes unnamed stratigraphic units older than the Sautou Fm as defined above. Finally, these authors discovered a roofing slate seam, not described by Beugnies, which thickness of $8-10 \mathrm{~m}$ indicates that it could be the lateral equivalent of the Peureux Mbr of the Rocroi Inlier. Finally, Vanguestaine \& Léonard (2005) questioned the relevance of the geological maps of the Givonne Inlier published by Beugnies $(1960 b, 1962)$ given the results of their study.

Nevertheless, the work of these authors, in particular on the Claire-Terne de la Borne section (Vanguestaine \& Léonard, 2005 , figs 6,8 ), will allow us, thanks to the identification of the acritarch biozones, to correlate the three lower units of the Revin Group with those of the neighbouring Rocroi Inlier.

\subsubsection{The unnamed formation equivalent to the Rocher de l'Uf Fm (Rvl) of the Rocroi Inlier}

This unnamed formation is located in the centre of the Bosséval Anticline of the Claire-Terne de la Borne section where it contains acritarchs from Zone 1 (Vanguestaine \& Léonard, 2005 , figs 6, 8). Beugnies $(1960 \mathrm{~b}, 1962)$ interpreted this section as the upper part of the Illy Fm (Rv3). In view that the acritarchs indicate Zone 1, it is highly probable that this lithostratigraphical unit which also contains acritarchs of Zone 1, can be the lateral equivalent of the Rocher de 1'Uf Fm (Rv1) in the neighbouring Rocroi Inlier. An additional argument is the discovery of a roofing slate seam, a few tens of metres under the dated unit, all the characteristics of which, in particular its thickness $(6-8 \mathrm{~m})$, correspond to the Les Peureux Mbr of the Rocroi Inlier (Fig. 3).

\subsubsection{Assignment of Zone 2 identified in the Claire-Terne de la Borne section}

On either side of the core of the anticline in the Claire-Terne de la Borne section, Vanguestaine \& Léonard (2005) identified acritarchs of Zone 2. However, Beugnies (1960b) recognized there the Illy and Sautou formations. As these two intervals (on either side of the anticline) belong to Zone 2, it is possible to correlate it with Zone 2 present in the lower part of the Roche à Sept Heures Fm (Rv2 of the Rocroi Inlier). Given the observational gaps in the section, acritarchs of Zone 3, which should follow, are not observed, nor the roofing slate marker at its top (Vanguestaine \& Léonard, 2005, figs 6, 8). Nevertheless, we will see in the following section, that this Zone 3 is identified in two other places.

\subsubsection{Position of Zone 3 and Zone $4 b$}

In the Falizette section, Vanguestaine \& Léonard (2005, fig. 5) showed Zone $4 \mathrm{~b}$ overlying an undifferentiated Zone 4. Given that they record Stelliferidium? sp. A and Lophosphaeridium? kryptoradiatum, one can see why they referred it to Zone 4 , but this does not exclude that these forms first appear in Zone 3 (Molyneux, pers. comm., 2021). This might fit the lithological succession better as the roofing slate seam Olly Mbr is observed just between the two zones (Vanguestaine \& Léonard, 2005, fig. 5). The Olly Mbr, a few metres thick, forms the boundary between the La Chapelle (Rv2) and the Illy (Rv3) formations in the lithostratigraphy of Beugnies $(1960 \mathrm{~b}, 1962)$. Moreover, Zone 3 was observed by Vanguestaine (1977, fig. 8) to the $\mathrm{N}$ of Moulin Chicot which belongs to the Falizette section. Zone $4 \mathrm{~b}$ is also observed at the northern end of the Claire-Terne de la Borne section where, given the anticlinal structure, it would be logical for it to succeed Zone 3 (Vanguestaine \& Léonard, 2005, fig. 8).

These observations strongly suggest:

- that Zone 3 not observed in the Rocroi Inlier is present in La Chapelle Fm sensu Beugnies (1960b). This last formation is similar in aspect to the La Roche à Sept Heures Fm. Without proving it, there is an additional argument that the roofing slates of the Olly Mbr are a lateral equivalent of the La Folie Mbr (Fig. 3);

- that Zone $4 b$ is the equivalent of the Anchamps Fm of the Rocroi Inlier (Fig. 3).

\subsubsection{Conclusions}

It has been possible for me, with difficulty given many contradictions and imprecision in the literature, to correlate three new formations in the Givonne Inlier with their lateral equivalents in the Rocroi Inlier. They are not named because they do not correspond to the stratigraphic nomenclature proposed by Beugnies (1960b, 1962), except for the Olly Mbr. These three unnamed formations can be dated via the acritarchs biozonations from the Wuliuan to the Paibian (Fig. 3).

However, this should be considered as tentative requiring further research to be confirmed. In the same order of thought, Beugnies (1960b) mapped the $>400 \mathrm{~m}$ thick Pourru-aux-Bois Fm (Rv5), subdivided in members, that could correspond to the Petite-Commune (Rv4) and Vieux-Moulin de Thilay (Sm3) formations of the Rocroi Inlier (Fig. 3). This also needs future research.

\section{Discussion on geological implications}

\subsection{Learnings from the graphical synthesis}

Figure 7 shows the stratigraphic correlations of the formations in the Brabant Massif and the two major inliers of the Ardenne, Stavelot-Venn Inlier and Rocroi Inlier, from the lower Cambrian to the Middle Ordovician. Formations belonging to Megasequences 1 and 2 (e.g. Woodcock, 1991; Vanguestaine, 1992; Verniers et al., 2002) are coloured in yellow and green respectively and the large-scale tectonic events allow inferences to be made. Figure 8 is more comprehensive as it compares the same three areas from the lower Cambrian to the Devonian as well as the three megasequences with their thicknesses and, of importance, the magmatic events (Linnemann et al., 2012; Herbosch et al., 2020). These two graphical syntheses allow for some interesting global observations, some of which are well known but have not been satisfactorily explained:

- The sedimentary record of these three areas begins simultaneously even if the alignment of their base in the Terreneuvian Series, around c. $525 \mathrm{Ma}$, has only weak stratigraphic arguments to support it. Their lithology is predominantly sandstone and their depositional environments are interpreted as shallow, while the major part of the subsequent sedimentary record is mostly deep oceanic (Beugnies, 1963; von Hoegen et al., 1985; Geukens, 1963; Verniers et al., 2002; Herbosch \& Verniers, 2013).

- Megasequence 1 occurs in all three areas but is significantly thicker in the Brabant Massif ( $>9 \mathrm{~km}$; Fig. 8). It is interrupted by a stratigraphic hiatus at the beginning of 


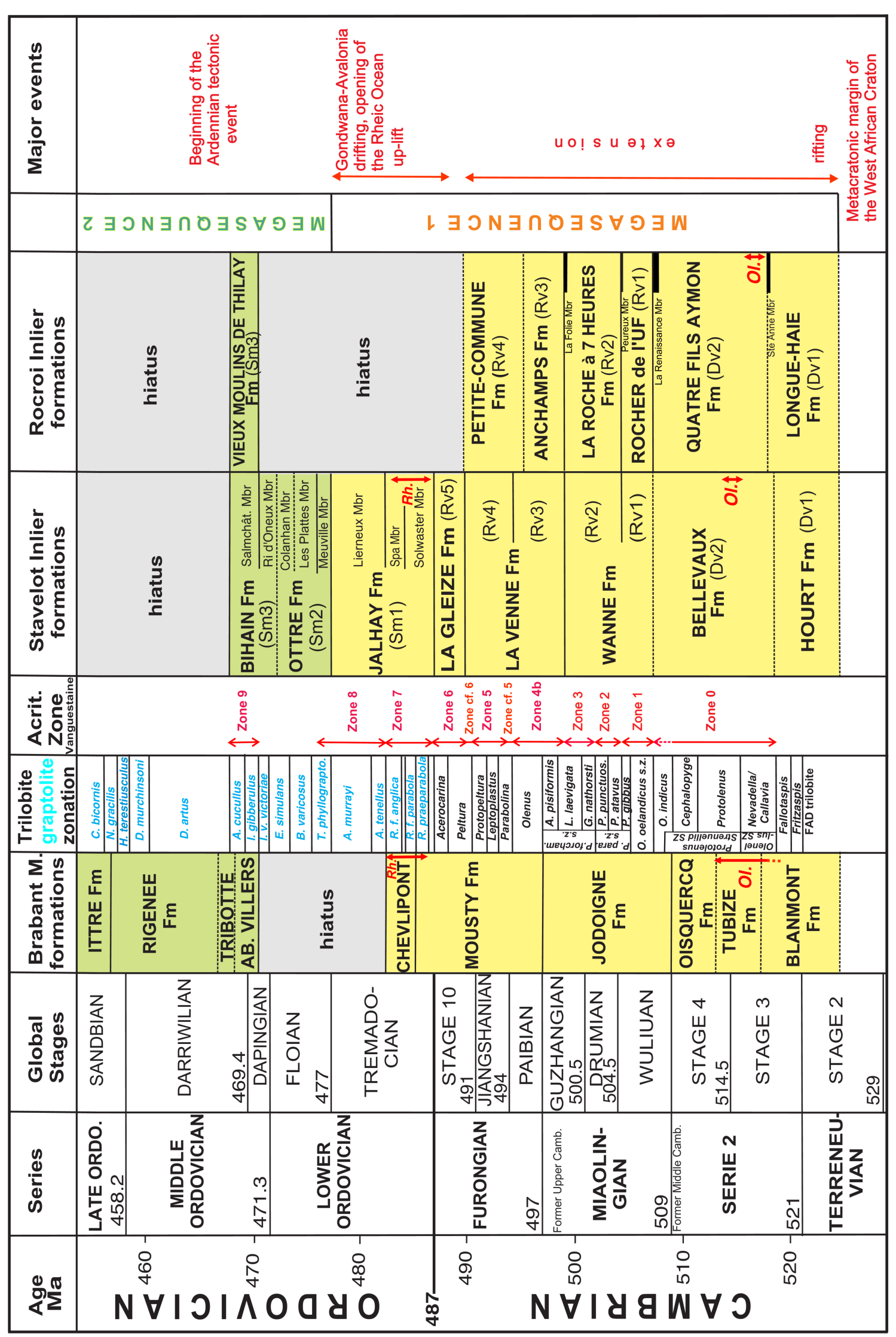

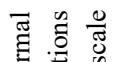

号 喿

\&

है

을

$\Xi$ 的

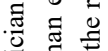

항

ơ 道

券

我离

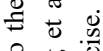

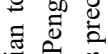

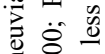

范

西要

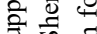

\& $\infty$

च

$\leftrightarrow$ 过

过

듬

동.

궁

$>$ 응

递㤩离

in

记

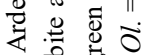

施

पै

흘 든

다을

类

年

喝 $\sum_{0}$

글 줄

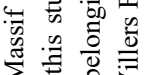

政

旸

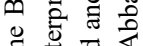

를

竎芯

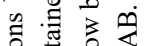

跑

동 을 윻

햅 $\overrightarrow{0}$ 


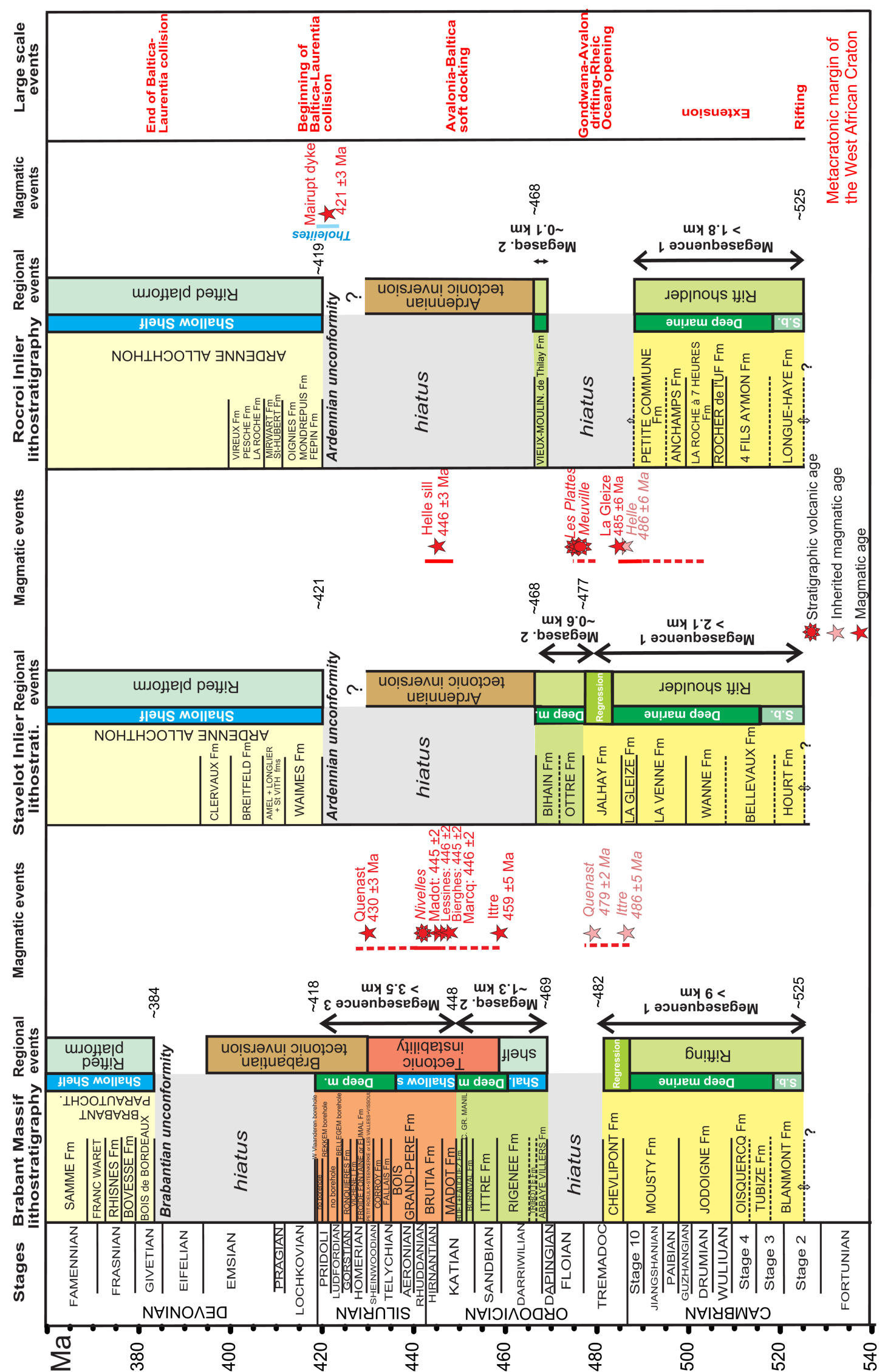

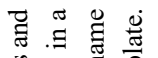

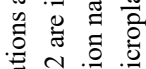

记

응

政

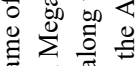

ㄷำ

웡

它

形我品

疍

을

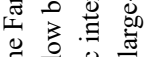

总范

秀.

施

이 $\rightarrow$ z

罂

흥

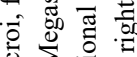

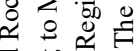

壳 离

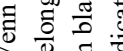

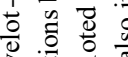

证

० 요 0

छ

这政

政

응

क⿺辶大

券

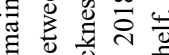

일

施

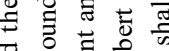

要

密

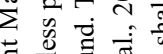

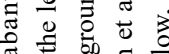

ต

$\Xi$ क

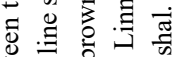

च

응

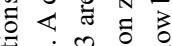

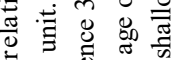

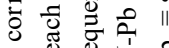

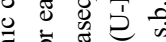

충

熙

部范获

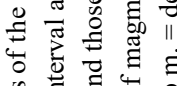

일 명

क्ष

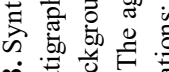
$\infty$ 政 
the Ordovician in the Brabant Massif and Rocroi Inlier but not in the Stavelot-Venn Inlier where sedimentation is continuous until the beginning of the Middle Ordovician (Lamens, 1985; Verniers et al., 2002; Herbosch \& Verniers, 2014).

- Megasequence 2 is greatly reduced in time and thickness in the Stavelot-Venn Inlier $(\sim 0.6 \mathrm{~km}, \sim 10 \mathrm{Ma})$ and Rocroi Inlier $(\sim 0.1 \mathrm{~km}, \sim 2 \mathrm{Ma})$. It is moderate in the Brabant Massif (about $1.3 \mathrm{~km}$ ) but extends to the Upper Ordovician ( 20 Ma).

- Megasequence 3 is absent (stratigraphic hiatus) in the Ardenne inliers and continuous until the top of the Silurian in the Brabant Massif.

- At the Dapingian-Darriwilian boundary, sedimentation resumes in the Brabant Massif while it stops in the two Ardenne inliers.

- Concerning magmatism, which is not the subject of this paper, the reader is referred to Herbosch et al. (2020) who overview previous research and describe new data followed by a new interpretation. In short, magmatism is essentially intermediate to felsic in the Brabant Massif and StavelotVenn Inlier and tholeiitic in the Rocroi Inlier. The acme of acid magmatism concentrated at the Ordovician-Silurian transition (450-440 Ma; Fig. 8) and that of the Rocroi Inlier is extremely brief and dated to the upper Pridoli (see $\S 9.4$ ).

- The Brabant Massif was affected only by the Caledonian orogeny whereas the Ardenne inliers were affected first by the Caledonian and then by the Variscan orogeny (Fig. 8). This last hypothesis is disputed by some authors who minimize the importance of a Caledonian folding (see references in $\S 9.4$ ).

The explanations for these observations, sometimes conflicting, are essentially due to large-scale tectonic events linked to the history of the Avalonia microplate from the Cambrian to the Devonian. This story starts at the beginning of the Cambrian with its location at the western edge of the West African Craton (present position), then continues at the beginning of the Ordovician with its drifting from Gondwana and opening of the Rheic Ocean. This continues with its rapid northward drift into the Iapetus Ocean, its soft docking with Baltica in the Upper Ordovician, and ends during the Devonian with the collision of Baltica-Avalonia with Laurentia closing the Iapetus Ocean (e.g. recent review papers Herbosch et al., 2020; Cocks \& Torsvik, 2021). In the following sections, we will take a closer look at some events in the history of the Avalonia microplate that have recently come into focus.

\subsection{The Cambrian palaeogeographical position of Avalonia and its subsequent rifting from Gondwana}

The palaeogeographical position of Avalonia during the Cambrian, before drifting, has been located off West Africa (see overview in Domeier, 2016; Cocks \& Torsvik, 2021) or even off South America (e.g. Nance et al., 2008). Based on a detailed interpretation of the detrital zircon age spectra and on rheological considerations, Herbosch et al. (2020, fig. 20) proposed a more constrained palaeogeographical position for Avalonia before its drifting from Gondwana. The RhenoHercynian basement forms a protuberance located at the SE extremity of Avalonia (Fig. 9C) which corresponds exactly in size to the actual western embayment of the West African craton observed on the southern coast of Mauritania and Senegal.

Herbosch et al. (2020, fig. 20) then proposed that the RhenoHercynian basement was ripped off the West African metacratonic margin during the drifting of Avalonia from Gondwana (Fig. 9) in the lowermost Ordovician (e.g. Cocks \& Torsvik, 2005; 2021; Domeier, 2016). This is consistent with

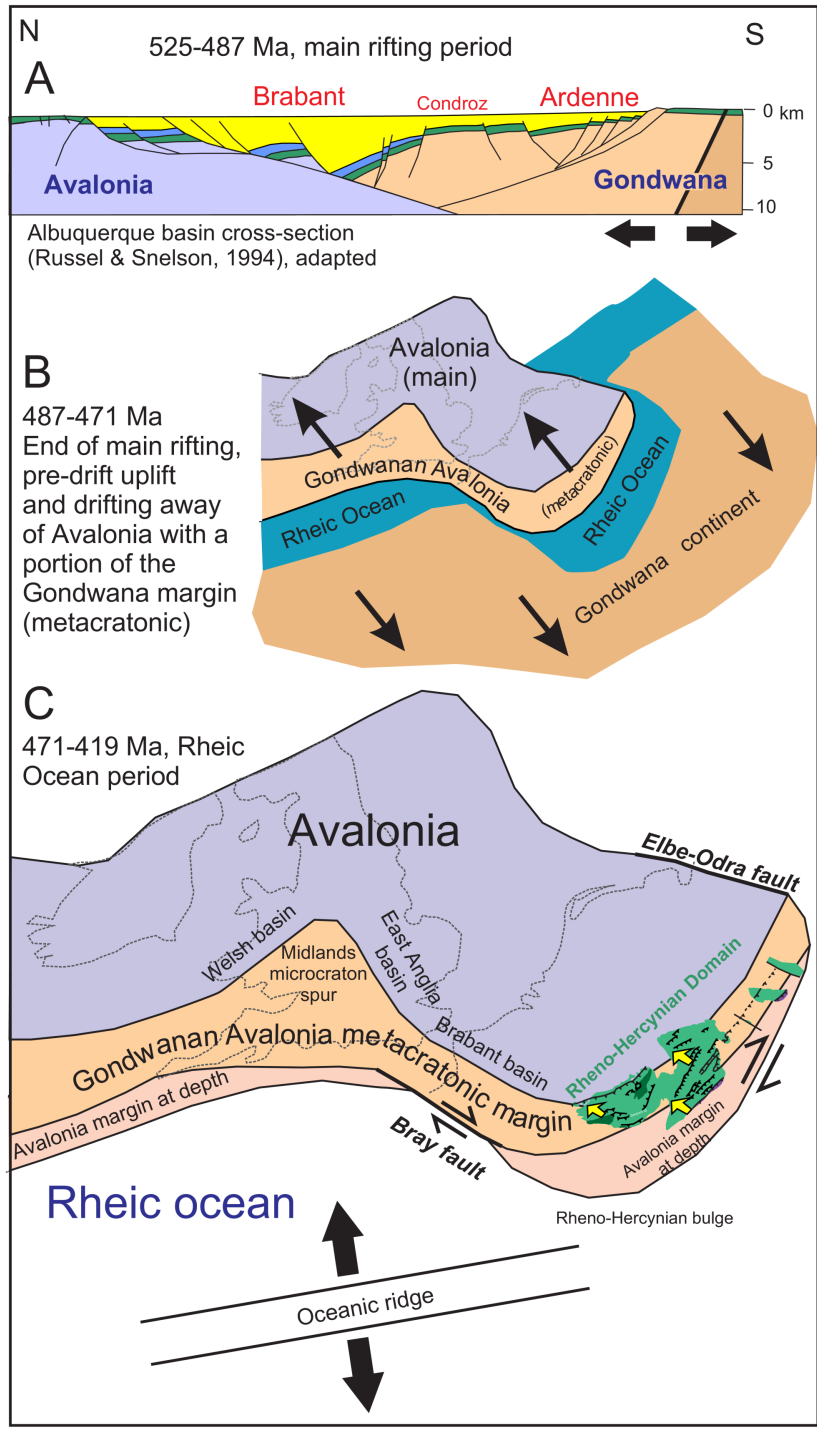

Figure 9. Geodynamic model proposed for Cambrian to Silurian history of E Avalonia by Herbosch et al. (2020). A: Cambrian rifting period (Terreneuvian to Furongian, 525-487 Ma). This cross-section is based on the present-day structure of the Albuquerque Basin from New Mexico (Russel \& Snelson, 1994) transposed to the Brabant Massif located in the most subsident zone (rift) and the Ardennes located on the shoulder of the rift separated by the Condroz shoal. B: During Lower Ordovician (Tremadocian-Floian; 487-471 Ma), the Rheic Ocean opened to the $\mathrm{E}$ of the Brabant-Ardenne rift zone, within the Gondwana fractured basement. The southern margin of Avalonia is thus made of a Gondwana metacratonic margin, which meets the lithospheric zones proposed by Smit et al. (2018). C. The Middle Ordovician-uppermost Silurian (471-419 Ma) corresponds to the main lifespan of the Rheic Ocean whose medio-oceanic ridge can apply stress on the $\mathrm{S}$ margin of Avalonia, especially during the docking of Avalonia with Baltica (around $448 \mathrm{Ma}$ ) and later with Laurentia (from $430 \mathrm{Ma}$ ). This induced strike-slip movements along the SW boundary (Bray Fault) of Avalonia and along its eastern margin (Rheno-Hercynian Domain margin). Modified from Herbosch et al. (2020). 
the SE extension of the Midlands microcraton under the southern part of the Brabant Massif and under the Ardenne, which has already been proposed by several authors (Blundell, 1993; Chacksfield et al., 1993; Sintubin, 1999; Sintubin \& Everaerts, 2002). It is geophysically demonstrated by Smit et al. (2018), who showed that a large part of the Rheno-Hercynian domain is above the Avalonia microcraton (Fig. 9C). In the new configuration proposed by Herbosch $(2020$, figs 18,19$)$ the Brabant Massif lies above the Gondwanan metacratonic margin (SE extension of the Midlands microcraton) in its southern part (Fig. 9C) and above the Southern North Sea-Lüneburg terrane to the NE (Sintubin \& Everaerts, 2002, fig. 10; Sintubin et al., 2009, fig. 11). This metacratonic margin, on which the Ardenne Allochthon is located, was bordered to the $\mathrm{N}$ by several subsiding basins: Brabant, East Anglia, and Welsh (Fig. 9C).

Major events affecting the Avalonia microplate (see § 9.1) allow us to explain why sedimentation begins more or less simultaneously in the Brabant Massif and in the Ardenne inliers. Indeed, while proto-Avalonia was still part of Gondwana in the lower Cambrian (Fig. 9A) a rift began to form initially on the shelf which rapidly deepened. Subsidence is much more important in the Brabant Massif, which is located on a different, less rigid basement.

\subsection{The Brabant Massif and the Ardenne inliers form a single basin with contrasted basement}

Although the Brabant Massif and the Condroz Inlier have already been shown to form a single sedimentation basin (Verniers et al., 2002; Herbosch \& Verniers, 2014), its extension to the Ardenne inliers had only been suggested (Owens \& Servais, 2007; Linnemann et al., 2012). It is only recently that this has been further investigated (Herbosch et al., 2020). These authors promote the hypothesis that the Brabant Massif and the Ardenne inliers formed a single basin from the lower Cambrian to the Middle Ordovician.

The apparently contradictory observations made earlier (see § 9.1) concerning the thicknesses and the hiatuses between the different areas can be reconciled if we adopt the hypothesis of a more rigid basement is present under the Ardenne inliers. The Brabant Massif being located in a much more subsiding region belonging to a failed arm of the rift that led to the Rheic Ocean opening (Verniers et al., 2002). Given this context, it can be assumed that the Ardenne inliers were located on one shoulder of the Brabant Massif rift (Herbosch et al., 2020). Rheological contrasted behaviours between rift and its shoulder are well known and continue to display contrasted evolution after the ocean opened (e.g. Faleide et al., 2008). In this hypothesis, the Brabant Massif being located in the rift itself will be affected by much more deepening under extension than the Ardenne inliers with their more rigid basement. This rift shoulder was probably composed of distinct blocks which may have moved vertically in relation to each other, and which would explain the presence of a hiatus in the Lower Ordovician of the Rocroi Inlier and only a regression in the Stavelot-Venn Inlier (Fig. 8). When subjected to compressive stress, the Brabant Massif deforms and lifts more easily, which is the cause of the hiatus resulting from the Baltica-Laurentia collision (Fig. 8).

\subsection{The Ardenne inliers have been affected by the Caledonian orogeny: new arguments}

The age and the nature of the event responsible for the Ardennian unconformity are an old debate that lasts since the beginning of geological research in the Ardenne. Briefly, it can be said that a large number of authors (i.e. Beugnies, 1963; Delvaux de Fenffe \& Laduron, 1991; Bélanger et al., 1997;
Bélanger, 1998; Geukens, 1999) tends to the view that the Ardenne inliers underwent two orogenic phases, a Caledonian phase of general poorly defined Ordovician age and a Variscan phase that is well documented and dated from the upper Carboniferous. However, Van Baelen \& Sintubin (2008) and Sintubin et al. (2009) argue, on the basis of very detailed but local studies in Stavelot and Rocroi inliers, that there are no structural arguments in favour of the occurrence of an Ardennian orogenic event. For them, the angular discordance observed all around the Ardenne inliers reflects the late Silurian/ Early Devonian onset of the Rheno-Hercynian basin development. However, this study provides three new arguments in favour of the existence of a mid-Ordovician Caledonian orogenic event:

(1) The highest stratigraphic units in both the Rocroi and Stavelot-Venn inliers are of the same age. This is well shown by the presence of the same acritarch biozone (Zone 9) in both topmost strata (see $\S 5.8$ ), indicating a late Dapingian to early Darriwilian age (Figs 3,7). This gives a time-based argument in favour of a tectonic event that caused a simultaneous uplift and emergence of the Ardenne inliers at the beginning of the Middle Ordovician, even if we know that the presence of these highest layers is not a proof of ending of sedimentation.

(2) Palaeocurrent data obtained in the Brabant Massif for the late Ordovician and Silurian turbidites suggest currents directed on average northwards (Debacker et al., 2014). In details: NNW in the Llandovery to Wenlock of the Méhaigne (Verniers \& Van Grootel, 1991), northwards in the Wenlock of the Orneau (Verniers \& Van Grootel, 1991), northwards in the Ludlow of the Sennette (Louwye et al., 1992), northwards current and N dipping slope for the Wenlock of the Orneau (Debacker et al., 2014). These observations suggest that the Ardenne basement, made predominantly of fine-grained siliciclastic rocks, represents a likely source area for the mud-dominated turbidites of the Brabant-Condroz Silurian foreland basin (Debacker et al., 2014). This statement is supported by the presence of freshly reworked Lower-Middle Ordovician acritarchs throughout the Silurian of the Condroz Inlier, the source area of which should be located to the $\mathrm{S}$ of the Condroz, i.e. the Ardenne inliers (Martin, 1969a, b, 1974).

(3) It has been demonstrated in the Rocroi Inlier (Meilliez, 1981; Goffette et al., 1990; Goffette, 1991) that the magmatic dykes "cut folds in the Cambrian formations, and are themselves affected by the penetrating cleavage that affects the basement and the cover" (Meilliez \& Lacquement, 2006, p.73). The intrusion of these dykes occurred by hydraulic fracturing in an extremely short time, geologically instantaneous (Goffette, 1991). It can thus be considered that the $421 \pm 3$ Ma age (Pridoli) obtained on the felsic Mairupt dyke (Cobert et al., 2018) is that of the whole dyke swarm. We can therefore deduce that the Rocroi Inlier was folded before the Silurian-Devonian boundary (419 Ma; Gradstein et al., 2020), i.e. during an early Caledonian phase.

Put together, these independent but convergent arguments are strongly in favour of a Caledonian tectonic event. This event must be post lower Darriwilian (Middle Ordovician), the age of the youngest sediments affected by this event in the StavelotVenn Inlier and Rocroi Inlier (Fig. 8). It must also be pre-Pridoli for the Rocroi Inlier dykes, and before the mid Silurian for the Brabant Massif foreland basins (Van Grootel et al., 1997). This age also corresponds to the magmatic flare-up on both sides of the Katian-Hirnantian boundary in the Brabant Massif and in Stavelot-Venn Inlier (Helle sill; Fig. 8). There is also evidence for a tectonic activity at about this time in the Welsh Basin, dated as late Katian, and referred to as Shelveian event (e.g. Pharaoh, 2018). Altogether, this points to a Middle to Upper Ordovician age for this Caledonian tectonic event. The latter age 
could be considered as the time of the climax of the Ardennian tectonic event, which can be considered as a far-distant effect of the Avalonia-Baltica docking in an intracontinental setting (Herbosch et al., 2020).

\section{Conclusions}

The Ardenne inliers and Brabant Massif both belong to the Avalonia microplate but only the Ardenne inliers have been affected by the Variscan orogeny. This implies that the correlations between these two Cambro-Ordovician basements are not straightforward and have been much discussed but not updated. This work, by taking up all the literature concerning the litho-, bio- and chronostratigraphy of the Brabant Massif and the three main inliers of the Ardenne, i.e. Stavelot-Venn, Rocroi and Givonne, has been able to achieve the following:

- to more accurately correlate Vanguestaine's 13 informal acritarch biozones with the most recent geological time scale (Gradstein et al., 2020);

- to establish an up to date chronostratigraphy of the formations of the Brabant Massif and the Stavelot-Venn Inlier;

- to establish a completely new chronostratigraphic position of the formations of the Rocroi and Givonne inliers;

- concerning the Givonne Inlier, Vanguestaine \& Léonard (2005) proved that the lithostratigraphy used so far should be redone. The units used are without definition, but no new formal or informal units are proposed by them nor in the present paper.

However, it is necessary to point out that the boundaries between formations, represented in dashed lines in Figures 3, 5, 7 and 8, are less precise than those represented in solid lines. Similarly, the biostratigraphic correlations between the Ardenne inliers, in particular between the Rocroi Inlier and the Givonne Inlier, must also be taken with a certain amount of caution as explained above (see $\S 8.4 .5$ ).

This synthesis, summarised in Figures 7 and 8, allows more general inferences to be drawn in relation to the eventful tectonic history of the SE part of the Avalonia microplate. The sedimentation of the Caledonian basement from Belgium and neighbouring countries starts more or less simultaneously within Stage 2 following the formation of a rift that affects protoAvalonia (e.g. Verniers et al., 2002), which was still part of the Gondwana continent. The Brabant Massif is located in the much more subsiding region belonging to a failed arm of the rift that led to the Rheic Ocean opening. Then, following the proposition of Herbosch et al. (2020), the basement of the Rheno-Hercynian domain can be assumed to be a piece of lithosphere ripped off from the margin of the West African craton during the opening of the Rheic Ocean (Fig. 9).

In a general way, the strong resemblance of the depositional environments (mostly deep and anoxic) and stratigraphic similarities that can be observed between the Brabant Massif and the Ardenne inliers demonstrate that they were deposited in one single sedimentary basin. The differences, which are mainly observed from the Ordovician onwards (Megasquence 2; Fig. 8), can be explained by contrasted basement, the Ardenne inliers corresponding to a more rigid rift shoulder while the Brabant Massif was located in the rift itself (Herbosch et al, 2020; Fig. 9A).

Finally, this work provides new arguments-particularly the synchronicity of the end of sedimentation in the Stavelot-Venn and Rocroi inliers, which is earlier in the Middle Ordovician than previously proposed, and the Pridoli age of the dykes that intersect the folds of the Rocroi Inlier-which tends to demonstrate, in addition to the arguments from the literature, that the Ardenne inliers were affected by a phase of the
Caledonian orogeny as early as the Middle Ordovician.

\section{Acknowledgements}

My thanks to J.-P. Liégeois for the numerous and fruitful discussions concerning the magmatism and tectonics of the Avalonian basement, as well as to T. Servais for his help in the field of micropalaeontology. I would also like to thank F. Lacquement for sharing some Vanguestaine results concerning unpublished micropalaeontological investigations carried out in the Rocroi Inlier. I thank the Département des Géosciences, Environnement et Société from the Université Libre de Bruxelles for the authorization to continue my research activities during my retirement. My thanks to S. Molyneux, T. Servais and J. Verniers for their particularly meticulous correction and comments which greatly improved the text as well to Annick Anceau for her efficient and helpful editorial work.

\section{References}

André, L., Herbosch, A., Louwye, S., Servais, T., Van Grootel, G. Vanguestaine, M. \& Verniers, J., 1991. Guidebook to the excursion on the stratigraphy and magmatic rocks of the Brabant Massif, Belgium. Annales de la Société géologique de Belgique, 114, 283-323.

Anthoine, R. \& Anthoine, P., 1943. Les assises de Mousty et de Villersla-Ville du bassin supérieur de la Dyle. Annales de la Société géologique de Belgique, 66, M53-M170.

Asselberghs, E., 1946. L'Eodévonien de l'Ardenne et des régions voisines. Mémoires de l'Institut géologique de l'Université de Louvain, 14, 598 p.

Bélanger, I., 1998. Effet d'une déformation hétérogène sur un ensemble mécaniquement anisotrope: le cas du Massif de Rocroi (Ardenne franco-belge). Unpublished Ph.D. Thesis, Université Catholique de Louvain, Louvain-la-Neuve, 248 p

Bélanger, I., Sintubin, M. \& Laduron D., 1997. Strain analysis along the southern border of the Rocroi Massif (Belgian-French Ardennes). Aardkundige Mededelingen, 8, 1-4.

Bélanger, I., Delaby, S., Delcambre, B., Ghysel, P., Hennebert, M., Laloux, M., Marion, J-M., Mottequin, B. \& Pingot, B., 2012. Redéfinition des unités structurales du front varisque utilisées dans le cadre de la nouvelle Carte géologique de Wallonie (Belgique). Geologica Belgica, 15, 169-175.

Bergström, S.M., Chen, X., Gutierez-Marco, J.C. \& Dronov, A., 2009. The new chronostratigraphic classification of the Ordovician System and its relations to major regional series and stages and to $\delta^{13} \mathrm{C}$ chemostratigraphy. Lethaia, 42, 97-107. https:// doi.org/10.1111/j.1502-3931.2008.00136.x

Beugnies, A., 1960a. Le Massif cambrien de Givonne. Annales de la Société géologique de Belgique, 83, M1-M39.

Beugnies, A., 1960b. Stratigraphie comparée du Cambrien des Massifs ardennais. Bulletin de la Société belge de Géologie, de Paléontologie et d'Hydrologie, 69, 91-106.

Beugnies, A., 1962. Compte rendu de la session extraordinaire de la Société géologique de Belgique du 15 au 18 septembre 1961. Annales de la Société géologique de Belgique, 85, 1-84.

Beugnies, A., 1963. Le Massif cambrien de Rocroi. Bulletin du Service de la carte géologique de la France, 59/270, 520 p.

Blundell, D.J., 1993. Deep structure of the Anglo-Brabant massif revealed by seismic profiling. Geological Magazine, 130, 563-567. https://doi.org/10.1017/S0016756800020859

Breuer, P. \& Vanguestaine, M., 2004. The latest Tremadocian messaoudensis-trifidum acritarch assemblage from the upper part of the Lierneux Member (Salm Group, Stavelot Inlier, Belgium). Review of Palaeobotany and Palynology, 130, 41-58. https:// doi.org/10.1016/j.revpalbo.2004.01.003 
Candela, Y., Marion, J-M., Servais, T., Wang, W., Wolvers, M. \& Mottequin, B., 2021. New linguiformean brachiopods from the lower Tremadocian (Ordovician) of the Brabant Massif, Belgium, with comments on contemporeaneous faunas from the StavelotVenn Massif. Rivista Italiana di Paleontologica e Stratigraphica, 127, 383-395. https://doi.org/10.13130/2039-4942/15793

Catot, E., 1991. Contribution à l'étude des acritarches du Salmien inférieur du Massif de Stavelot. Unpublished Master Thesis, Université de Liège, Liège, $129 \mathrm{p}$.

Catot, E., 1992. Contribution à l'étude des acritarches du Salmien inférieur du Massif de Stavelot. Annales de la Société géologique de Belgique, 115, 371.

Chacksfield, B.C., De Vos, W., D’Hooge, L., Dusar, M., Lee, M.K., Poitevin, C., Royles, C.P. \& Verniers, J., 1993. A new look at Belgian aeromagnetic and gravity data through image-based display and integrated modelling techniques. Geological Magazine, 130, 583-591. https://doi.org/10.1017/S0016756800020884

Cobert, C., Baele, J.M., Boulvais, P., Poujol, M. \& Decrée, S., 2018. Petrogenesis of the Mairupt microgranite: A witness of an Uppermost Silurian magmatism in the Rocroi Inlier, Ardenne Allochton. Comptes Rendus Geoscience, 350, 89-99. https:// doi.org/10.1016/j.crte.2017.12.001

Cocks, L.R.M. \& Torsvik, T.H., 2002. Earth geography from 500 to 400 million years ago: a faunal and palaeomagnetic review. Journal of the Geological Society, London, 159, 631-644. https:// doi.org/10.1144/0016-764901-118

Cocks, L.R.M. \& Torsvik, T.H., 2005. Baltica from the late Precambrian to mid-Palaeozoic times: the gain and loss of a terrane's identity. Earth-Science Reviews, 72, 39-66. https://doi.org/10.1016/ j.earscirev.2005.04.001

Cocks, L.R.M. \& Torsvik, T.H., 2021. Ordovician palaeogeography and climate change. Gondwana Research, 100, 53-72. http:// doi.org/10.1016/j.gr.2020.09.008

Cooper, A.H. \& Molyneux, S.G., 1990. The age and correlation of Skiddaw Group (early Ordovician) sediments in the Cross Fell inlier northern England). Geological Magazine, 127, 147-157.

Cooper, A.H., Fortey, N.J., Hughes, R.A., Molyneux, S.G., Rushton, A.W.A. \& Stone, P., 2004. The Skiddawn Group of the English Lake District. British Geological Survey, Keyworth, British Geological Survey Memoir for the 1:50,000 geological map sheets E22, 29, 29, 30, 31, 48.

Cooper, R.A., 1999. Ecostratigraphy, zonation and global correlation of earliest Ordovician planktic graptolites. Lethaia, 32, 1-16. https:// doi.org/10.1111/j.1502-3931.1999.tb00576.x

Cooper, R.A., Maletz, J., Haifeng, W. \& Erdtmann, B.D., 1998. Taxonomy and evolution of earliest Ordovician graptoloids. Norsk Geologisk Tidsskrift, 78, 3-32.

Debacker, T.N., Verniers, J., Strachan, L.N., Dumon, M. \& Belmans, M., 2014. Sedimentological thickness variations within Silurian mudstone-dominated turbidite deposits and the effects on cleavage fanning (Anglo-Brabant Deformation Belt, Belgium). Journal of the Geological Society, 171, 193-209. https://doi.org/10.1144/jgs2013-031

Delcambre, B. \& Pingot, J. L., 2002. Carte géologique de Wallonie : Chastre - Gembloux 40/5-6. 1/25 000. Ministère de la Région wallonne, Direction générale des ressources naturelles et de l'environnement, Namur, avec une notice explicative de $72 \mathrm{p}$.

Delvaux de Fenffe, D. \& Laduron, D., 1991. Caledonian and Variscan structures in the Rocroi-Ardenne Lower Palaeozoic basement (Belgium and adjacent countries). Annales de la Société géologique de Belgique, 114, 141-162.

De Vos, W., Verniers, J., Herbosch, A. \& Vanguestaine, M., 1993. A new geological map of the Brabant Massif, Belgium. Special issue on the Caledonides of the Anglo-Brabant Massif. Geological Magazine, 130, 605-611. https://doi.org/10.1017/ S0016756800020902

Domeier, M., 2016. A plate tectonic scenario for the Iapetus and Rheic oceans. Gondwana Research, 36, 275-295. https://doi.org/10.1016/ j.gr.2015.08.003
Faleide, J.I., Tsikalas, F., Breivik, A.J., Mjelde, R., Ritzmann, O., Engen, Ø, Wilson, J. \& Eldholm, O., 2008. Structure and evolution of the continental margin off Norway and the Barents Sea. Episodes, 31, 82-91. https://doi.org/10.18814/epiiugs/2008/ v31i1/012

Geyer, G. \& Shergold, J., 2000. The quest for internationally recognized divisions of Cambrian time. Episodes, 23, 188-195. https:// doi.org/10.18814/epiiugs/2000/v23i3/006

Geukens, F., 1949. Contribution à l'étude de la partie Nord-Ouest du massif cambrien de Stavelot. Mémoires de l'Institut géologique de Louvain, 16, 79-167.

Geukens, F., 1963. Un cyclothème dans le Rv3. Bulletin de la Société belge de Géologie, de Paléontologie et d'Hydrologie, 71, 504-507.

Geukens, F., 1981. Observations géologiques dans la région de Willerzie. Annales de la Société géologique de Belgique, 104, 67-73.

Geukens, F., 1999. Notes accompagnant une révision de la carte structurale du Massif de Stavelot. Aardkundige Mededelingen, 3, 15-30.

Geukens, F., 2008. Carte géologique de Wallonie : Bra - Lierneux 55/3-4. $1 / 25$ 000. Service public de Wallonie, Direction générale opérationnelle de l'Agriculture, des Ressources naturelles et de l'Environnement, Namur, avec une notice explicative de 38 p.

Goffette, O., 1991. Le magmatisme varisque en Ardenne méridionale: un marqueur de l'évolution géodynamique d'une paléomarge. Unpublished Ph.D. Thesis, Université de Lille, Lille, 317 p.

Goffette, O., Melliez, F. \& Gagny, C., 1990. Données nouvelles sur le magmatisme bimodal du Massif de Rocroi (Ardenne). Géologie de la France, 1, 3-17.

Goldman, D., Sadler, P.M. \& Leslie, S.A., 2020. The Ordovician period. In Gradstein, F.M., Ogg, J.G., Schmitz, M.D. \& Ogg, G.M (eds), Geologic Time Scale 2020.Elsevier, Amsterdam, 631-694. https:// doi.org/10.1016/B978-0-12-824360-2.00020-6

Gradstein, F.M., Ogg, J.G., Schmitz, M.D. \& Ogg, G.M., 2012. The Geologic Time Scale 2012. Elsevier, Amsterdam, 2 vol., 1144 p. https://doi.org/10.1016/C2011-1-08249-8

Gradstein, F.M., Ogg, J.G., Schmitz, M.D. \& Ogg, G.M., 2020. Geologic Time Scale 2020.Elsevier, Amsterdam, 2 vol., 1357 p. https://doi.org/10.1016/C2020-1-02369-3

Graulich, J.-M., 1961. Le sondage de Wépion. Annales des Mines de Belgique, 2, 156-161.

Herbosch, A. \& Lemonne, E., 2000. Carte géologique de Wallonie : Nivelles - Genappe 39/7- 8. 1/25 000. Ministère de la Région wallonne, Direction générale des ressources naturelles et de l'environnement, Namur, avec une notice explicative de $59 \mathrm{p}$.

Herbosch, A. \& Verniers, J., 2011. What is the biostratigraphic value of the ichnofossil Oldhamia for the Cambrian: a review. Geologica Belgica, 14, 229-248.

Herbosch, A. \& Verniers, J., 2013. Stratigraphy of the Lower Palaeozoic of the Brabant Massif, Belgium. Part I: The Cambro-Ordovician from the Halle and Ottignies groups. Geologica Belgica, 16, 49-65.

Herbosch, A. \& Verniers, J., 2014. Stratigraphy of the Lower Palaeozoic of the Brabant Massif, Belgium. Part II: The Middle Ordovician to lowest Silurian of the Rebecq Group. Geologica Belgica 17, 115-136.

Herbosch, A., Debacker, T.N. \& Piessens, K., 2008. The stratigraphic position of the Cambrian Jodoigne Formation redefined (Brabant Massif, Belgium). Geologica Belgica, 11, 133-150.

Herbosch, A., Liégeois, J.-P. \& Pin, C., 2016. Coticules of the Belgian type area (Stavelot-Venn Massif): Limy turbidites within the nascent Rheic Oceanic basin. Earth-Science Reviews, 159, 186214. https://doi.org/10.1016/j.earscirev.2016.05.012

Herbosch, A., Debacker, T., Dumoulin, V. \& Blockmans, S., 2019. Carte géologique de Wallonie : Jodoigne - Jauche 40/3-4. 1/25 000. Service Public de Wallonie, Direction générale opérationnelle de l'Agriculture, des Ressources naturelles et de l'Environnement, Namur, avec une notice explicative de 88 p.

Herbosch, A., Liégeois, J.-P., Gärtner, A., Hofmann, M. \& Linnemann, U., 2020. The Stavelot-Venn Massif (Ardenne, Belgium), a rift shoulder basin ripped off the West African craton: cartography, 
stratigraphy, sedimentology, new $\mathrm{U}-\mathrm{Pb}$ on zircon ages, geochemistry and $\mathrm{Nd}$ isotopes evidence. Earth-Science Reviews, 203, 103142. https://doi.org/10.1016/j.earscirev.2020.103142

Hildenbrand, A., Austermann, G., Ifrime, C. \& Bengston, P., 2021. Biostratigraphy and taxonomy of Drumian (middle Cambrian) agnostid trilobites of the Manuels River Formation, Avalonian Newfoudland, Canada. Papers in Paleontology, 7, 1657-1698. https://doi.org/10.1002/spp2.1358

Lacquement, F., 2001. L'Ardenne Varisque. Déformation progressive d'un prisme sédimentaire pré-structuré, de l'affleurement au modèle de chaîne. Société Géologique du Nord, Publication, 29, 285 p.

Lamens, J., 1985. Transition from turbidite to shallow-water sedimentation in the Lower Salmian (Tremadocian, Lower Ordovician) of the Stavelot Massif, Belgium. Sedimentary Geology, 44, 121-142. https://doi.org/10.1016/0037-0738(85)90036-3

Lecompte, M., 1948. Existence du Trémadocien dans le Massif du Brabant. Bulletin de l'Académie royale de Belgique, Classe des Sciences, 5e série, 34, 677-687.

Lecompte, M., 1949. Découverte de nouveaux gîtes à Dyctionema dans le Trémadocien du Massif du Brabant. Bulletin de l'Institut royal des Sciences naturelles de Belgique, 25, 1-8.

Léonard, R., 2004. Contrôle biostratigraphique de la cartographie du Massif de Givonne. Unpublished Master Thesis, Université de Liège, Liège, $50 \mathrm{p}$.

Linnemann, U., Herbosch, A., Liégeois, J.-P., Pin, C., Gärtner, A. \& Hofmann, M., 2012. The Cambrian to Devonian odyssey of the Brabant Massif within Avalonia: A review with new zircon ages, geochemistry, Sm-Nd isotopes, stratigraphy and palaeogeography. Earth-Science Reviews, 112, 126-154. https://doi.org/10.1016/ j.earscirev.2012.02.007

Louwye, S., Van Grootel, G. \& Verniers, J., 1992. The stratigraphy of the type locality of the ?late Wenlock/early Ludlow Mont Godart Formation and the early Ludlow Ronquières Formation, Brabant Massif, Belgium. Annales de la Société géologique de Belgique, 115, 307-331.

Malaise, C., 1874. Sur l'âge de quelques couches de terrains ordoviciens des environs de Spa. Bulletin de 1'Académie royale de Belgique, $2^{\mathrm{e}}$ série, 37, 800-801.

Malaise, C., 1876. Oldhamia radiata du Massif Devillien de GrandHalleux. Annales de la Société géologique de Belgique, 3, Bulletin, 70.

Malaise, C., 1878. Communication sur l'Oldhamia. Annales de la Société géologique de Belgique, 5, Bulletin, 58-59.

Malaise, C., 1900. Etat actuel de nos connaissances sur le Silurien de la Belgique. Annales de la Société géologique de Belgique, liber memorialis, 25 bis, in-4 $4^{\circ}, 179-221$.

Malaise, C., 1901. Sur le Silurien de Belgique. Congrès géologique International : Comptes rendus de la VIIIe session, en France. Imprimerie Le Bigot Frères, Paris, 561-571.

Maletz, J. \& Servais, T., 1998. Upper Ordovician graptolites from the Brabant Massif, Belgium. Geobios, 31, 21-37. https:// doi.org/10.1016/S0016-6995(98)80093-4

Mancy, J-L. \& Lacquement, F., 2006. Contexte géologique régional: l'Ardenne Paléozoïque ( $\mathrm{N}$ de la France et $\mathrm{S}$ de la Belgique). Géologie de la France, 1-2, 7-13.

Martin, F., 1969a. Ordovicien et Silurien belges: données nouvelles apportées par l'étude des Acritarches. Bulletin de la Société belge de Géologie, de Paléontologie et d'Hydrologie, 77, 175-181.

Martin, F., 1969b. Les acritarches de l'Ordovicien et du Silurien belges. Détermination et valeur stratigraphique. Mémoires de l'Institut royal des Sciences naturelles de Belgique, 160, 1-176.

Martin, F., 1974. Ordovicien supérieur et Silurien inférieur à Deerlijk (Belgique). Palynofacies et microfacies. Mémoires de l'Institut royal des Sciences Naturelles de Belgique, 174, 1-71.

Martin, F., 1976. Acritarches du Cambro-Ordovicien du Massif du Brabant. Bulletin de l'Institut royal des Sciences naturelles de Belgique, 51, 1-33.

Martin, F. \& Dean, W.T., 1988. Middle and Upper Cambrian acritarch and trilobite zonation at Manuels River and Random Island, Eastern
Newfoudland. Geological Survey of Canada, Bulletin, 381, 1-91. https://doi.org/10.4095/126418

Martin, F. \& Rickards, X., 1979. Acritarches, chitinozoaires et graptolites ordoviciens et siluriens de la vallée de la Sennette (Massif du Brabant, Belgique). Annales de la Société géologique de Belgique, 102, 181-197.

Meilliez, F., 1981. Filons magmatiques et structures plissées près de Revin (Ardenne). Compte rendu sommaire des séances de la Société géologique de France, 3, 101-104.

Meilliez, F. \& Lacquement, F., 2006. La discordance éodévonienne de l'Ardenne: structure du site de Fépin et conséquences sur les interprétations géodynamiques de l'Ardenne. Géologie de la France, 1-2, 73-77.

Meilliez, F. \& Lacquement, F., 2020. La cinématique du raccourcissement au Namuro-Westphalien. In Meilliez, F. \& Goemaere, E. (eds), Le Massif ardennais : un jeune massif ancien. Géochronique, 154, 29-34.

Meilliez, F. \& Vanguestaine, M., 1983. Acritarches du Cambrien moyen et supérieur à Montcornet-en-Ardenne (France): premières données et implications. Comptes Rendus de l'Académie des Sciences, Paris, Série 2, 297, 265-268.

Nance, R.D., Murphy, J.B., Strachan, R.A., Keppie, J.D., GutiérrezAlonso, G., Fernández-Suárez, J., Quesada, C., Linnemann, U., D'Lemos, R. \& Pisarevsky, S.A., 2008. Neoproterozoic-early Palaeozoic tectonostratigraphy and palaeogeography of the periGondwanan terranes: Amazonian v. West African connections. Geological Society, London, Special Publications, 297, 345-383. https://doi.org/10.1144/SP297.17

Ogg, J.G., Ogg, G. \& Gradstein, F.M., 2008. The Concise Geologic Time Scale. Cambridge University Press, Cambridge, 177 p.

Owens, R.M. \& Servais, T., 2007. The Ordovician of the Condroz Inlier, Belgium: Trilobites from the southeastern margin of Avalonia. Palaeogeography, Palaeoclimatology, Palaeoecology, 245, 272 294. https://doi.org/10.1016/j.palaeo.2006.02.025

Peng, S.C., Babcock, L.E. \& Ahlberg, P., 2020. The Cambrian period. In Gradstein, F.M., Ogg, J.G., Schmitz, M.D. \& Ogg, G.M. (eds), Geologic Time Scale 2020. Elsevier, Amsterdam, 565-629. https:// doi.org/10.1016/B978-0-12-824360-2.00019-X

Pharaoh, T., 2018. The Anglo-Brabant Massif: persistent but enigmatic palaeo-relief at the heart of western Europe. Proceedings of the Geologists' Association, 129, 278-328. https://doi.org/10.1016/ j.pgeola.2018.02.009

Rasul, S. \& Downie, C., 1974. The stratigraphic distribution of Tremadoc acritarchs in the Shineton Shale succession, Shropshire, England. Review of Palaeobotany and Palynology, 18, 1-10. https://doi.org/10.1016/0034-6667(74)90003-7

Ribecai, C. \& Vanguestaine, M., 1993. Latest-Middle Cambrian acritarchs from Belgium and northern France. Special Papers in Palaeontology, 48, 45-55.

Roche, M., Sabir, M., Steemans, P. \& Vangestaine, M., 1986. Palynologie du sondage et de la région de Willerzie. Aardkundige Mededelingen, 3, 149-190.

Russel, L.R. \& Snelson, S., 1994. Structural style and tectonic evolution of the Albuquerque Basin segment of the Rio Grande Rift, New Mexico, U.S.A. AAPG Memoir, 59, 205-258. https:// doi.org/10.1306/M59582C7

Samuelsson, J. \& Verniers, J., 2000. Ordovician chitinozoan biozonation of the Brabant Massif, Belgium. Review of Palaeobotany and Palynology, 113, 105-129. https:// doi.org/10.1016/S0034-6667(00)00055-5

Servais, T., 1991. Contribution to the stratigraphy of the Ordovician Rigenée Formation (Brabant Massif, Belgium) with a preliminary study on acritarchs. Annales de la Société géologique de Belgique, 114, 233-245.

Servais, T., 1993. A critical review of some Ordovician acritarch taxa and their stratigraphical implications in Belgium and Germany. Unpublished Ph.D. Thesis, Université de Liège, Liège, 3 vol., 380 p. 
Servais, T. \& Mette, W., 2000. The messaoudensis-trifidum acritarch assemblage (Ordovician: late Tremadoc-early Arenig) of the Barriga shale Formation, Sierra Morena (SW-Spain). Review of Palaeobotany and Palynology, 113, 145-163. https:// doi.org/10.1016/S0034-6667(00)00057-9

Servais, T., Molyneux, S.G., Li, J., Nowak, H., Rubinstein, C.V., Vecoli, M., Wang, W.H. \& Yan, K., 2017. First Appearance Datums (FADs) of selected acritarch taxa and correlation between Lower and Middle Ordovician stages. Lethaia, 51, 228-253. https:// doi.org/10.1111/let.12248

Sintubin, M., 1999. Arcuate fold and cleavage patterns in the southeastern part of the Anglo-Brabant Fold Belt (Belgium): tectonic implications. Tectonophysics, 309, 81-97. https:// doi.org/10.1016/S0040-1951(99)00133-X

Sintubin, M. \& Everaerts, M., 2002. A compressional wedge model for the Lower Palaeozoic Anglo-Brabant Belt (Belgium) based on potential field data. In Winchester, J.A., Pharaoh, T.C. \& Verniers, J. (eds), Palaeozoic amalgamation of Central Europe. Geological Society, London, Special Publications, 201, 327-343. https:// doi.org/10.1144/GSL.SP.2002.201.01.16

Sintubin, M., Debacker, T.N. \& Van Baelen, H., 2009. Early Palaeozoic orogenic events north of the Rheic suture (Brabant, Ardenne): a review. Comptes Rendus Geoscience, 341, 156-173. https:// doi.org/10.1016/j.crte.2008.11.012

Smit, J., van Wees, J.D. \& Cloetingh, S., 2018. Early Carboniferous extension in East Avalonia: 350 My record of lithospheric memory. Marine and Petroleum Geology, 92, 1010-1027. https:// doi.org/10.1016/j.marpetgeo.2018.01.004

Van Baelen, H. \& Sintubin, M., 2008. Kinematic consequences of an angular unconformity in simple shear: an example from the southern border of the Lower Palaeozoic Rocroi inlier (Naux, France). Bulletin de la Société géologique de France, 179, 73-87. https://doi.org/10.2113/gssgfbull.179.1.73

Van Grootel, G., Verniers, J., Geerkens, B., Laduron, D., Verhaeren, M., Hertogen, J. \& De Vos, W., 1997. Timing of magmatism, foreland basin development, metamorphism and inversion in the AngloBrabant fold belt. Geological Magazine, 134, 607-616. https:// doi.org/10.1017/S0016756897007413

Vanguestaine, M., 1973. Etude palynologique du Cambro-Ordovicien de Belgique et de l'Ardenne française. Systématique et biostratigraphie. Unpublished Ph.D. Thesis, Université de Liège, Liege, 366 p.

Vanguestaine, M., 1974. Espèces zonales d'acritarches du CambroTrémadocien de Belgique et de l'Ardenne française. Review of Palaeobotany and Palynology 18, 63-82. https:// doi.org/10.1016/0034-6667(74)90010-4

Vanguestaine, M., 1977. Critères palynostratigraphiques conduisant à la reconnaissance d'un plis couché revinien dans le sondage de GrandHalleux. Annales de la Société géologique de Belgique, 100, 249-276.

Vanguestaine, M., 1986. Progrès récents de la stratigraphie par Acritarches du Cambro-Ordovicien d'Ardenne, d'Irlande, d'Angleterre, du Pays de Galles et de Terre-Neuve orientale. Annales de la Société géologique du Nord, 55, 65-76.

Vanguestaine, M., 1991. Datation par acritarches des couches cambrotrémadociennes les plus profondes du sondage de Lessines (bord méridional du Massif du Brabant, Belgique). Annales de la Société géologique de Belgique, 114, 213-231.

Vanguestaine, M., 1992. Biostratigraphie par acritarches du CambroOrdovicien de Belgique et des régions limitrophes: synthèse et perspectives d'avenir. Annales de la Société géologique de Belgique 115, 1-18.

Vanguestaine, M., 2008. Early and Middle Ordovician acritarchs of the Senne-Sennette river valleys (Brabant Massif, Belgium) and their stratigraphic implications. Geologica Belgica, 11, 3-24.

Vanguestaine, M. \& Brück, P.M., 2008. A Middle and Late Cambrian age for the Booley Bay Formation, County Wexford, Ireland: New acritarch data and its implications. Revue de Micropaléontologie, 51, 67-95. https://doi.org/10.1016/j.revmic.2007.12.001
Vanguestaine, M. \& Léonard, R., 2005. New biostratigraphic and chronostratigraphic data from the Sautou Formation and adjacent strata (Cambrian, Givonne Inlier, Revin Group, northern France) and some lithostratigraphic and tectonic implications. Geologica Belgica, 8/4, 131-144.

Vanguestaine, M. \& Servais, T., 2002. Early Ordovician acritarchs of the Lierneux Member (Stavelot Inlier, Belgium): stratigraphy and palaeobiogeography. Bulletin de la Société géologique de France, 173, 561-568. https://doi.org/10.2113/173.6.561

Vanguestaine, M. \& Van Looy, J., 1983. Acritarches du Cambrien Moyen de la vallée de Tacheddirt (Haut-Atlas, Maroc) dans le cadre d'une nouvelle zonation du Cambrien. Annales de la Société géologique de Belgique, 106, 69-85.

Vanguestaine, M. \& Wauthoz, B., 2011. Acritarchs from the Abbaye de Villers and Tribotte Formations in their type section of the Thyle river valley (Middle Ordovician, Brabant Massif, Belgium) and their stratigraphic implications. Geologica Belgica, 14, 3-22.

Vanguestaine, M., Servais, T. \& Steemans, Ph., 1989. Biostratigraphy of 28 borehole in the Brabant Massif. Abstracts of the International Meeting on the Caledonides of the Midlands and the Brabant Massif, Brussels, 46.

Vanguestaine, M., Breuer, P. \& Lehnert, O., 2004. Discovery of an Early Ordovician conodont fauna in the Salm Group of the Stavelot Inlier, Belgium. Bulletin de l'Institut royal des Sciences naturelles de Belgique, Sciences de la Terre, 74-suppl., 39-48.

Vanguestaine, M., Brück, P.M., Maziane-Serraj, N. \& Higgs, K.T., 2001. Cambrian palynology of the Bray Group in County Wicklow and South County Dublin, Ireland. Review of Palaeobotany and Palynology, 120, 53-72. https://doi.org/10.1016/S0034-6667(01)00150-6

Vanmeirhaeghe, J., 2006. The evolution of the Condroz-Brabant Basin from Middle Ordovician to Llandovery: lithostratigraphical and chitinozoan biostratigraphical approach. Unpublished Ph.D. Thesis, Ghent University, Ghent, 263 p.

Verniers, J. \& Van Grootel, G., 1991. Review of the Silurian in the Brabant Massif, Belgium. Annales de la Société géologique de Belgique, 114, 163-193.

Verniers, J., Samuelsson, J., Van Grootel, G., De Geest, P. \& Herbosch, A., 1999. The Ordovician in Belgium: new litho- and biostratigraphical data with Chitinozoa from the Brabant Massif and the Condroz Inlier (Belgium). Acta Universitatis CarolinaeGeologica, 43, 93-96.

Verniers, J., Herbosch, A., Vanguestaine, M., Geukens, F., Delcambre, B., Pingot, J.-L., Belanger, I., Hennebert, M., Debacker, T., Sintubin, M. \& De Vos, W., 2001. Cambrian-Ordovician-Silurian lithostratigraphic units (Belgium). Geologica Belgica, 4, 5-38. https://doi.org/10.20341/gb.2014.042

Verniers, J., Pharaoh, T., Andre, L., Debacker, T., De Vos, W., Everaerts, M., Herbosch, A., Samuelsson, J., Sintubin, M. \& Vecoli, M., 2002. The Cambrian to mid Devonian basin development and deformation history of Eastern Avalonia, east of the Midlands Microcraton: new data and a review. In Winchester, J.A., Pharaoh, T.C. \& Verniers, J. (eds), Palaeozoic Amalgamation of Central Europe. Geological Society, London, Special Publications, 201, 47-93. https://doi.org/10.1144/GSL.SP.2002.201.01.04

von Hoegen, J., Lemme, B., Zielinski, J. \& Walter, R., 1985. Cambrian and Lower Ordovician in the Stavelot-Venn Massif: a model for the depositional history. Neues Jahrbuch für Geologie und Paläontologie, Abhandlungen, 171, 217-235.

Wang, W. \& Servais, T., 2015. A re-investigation of the Rhabdinopora flabelliformis fauna from the early Tremadocian 'Dictyonema Shale' in Belgium. Geologica Belgica, 18, 66-77.

Webby, B.D., Cooper, R.A., Bergström, S.M. \& Paris, F., 2004. Stratigraphic framework and time slices. In: Webby, B.D., Paris, F., Droser, M. \& Percival, I. (eds), The Great Ordovician Biodiversification Event. Columbia University Press, New York, 41-47.

Winchester, J.A. \& the PACE TMR Network, 2002. Palaeozoic amalgamation of Central Europe: new results from recent geological 
and geophysical investigations. Tectonophysics, 360, 5-21. https:// doi.org/10.1016/S0040-1951(02)00344-X

Woodcock, N.H., 1991. The Welsh, Anglian and Belgian Caledonides compared. In André, L., Herbosch, A., Vanguestaine, M. \& Verniers, J. (eds), Proceedings of the International Meeting on the Caledonides of the Midlands and the Brabant Massif. Annales de la Société géologique de Belgique, 114, 5-17.

Manuscript received 15.05.2021, accepted in revised form 24.08.2021, available online 26.11.2021. 